GABRIEL MADEIRA FERNANDES

\title{
A POÉTICA DA SINCERIDADE DE RUI KNOPFLI
}

São Paulo

2012 
GABRIEL MADEIRA FERNANDES

\section{A POÉTICA DA SINCERIDADE DE RUI KNOPFLI}

Dissertação apresentada à Faculdade de Filosofia, Letras e Ciências Humanas da Universidade de São Paulo para obtenção do título de Mestre em Letras. Área de concentração: Estudos Comparados de Literaturas de Língua Portuguesa.

Orientador: Mário César Lugarinho

São Paulo

2012 
Autorizo a reprodução e divulgação total ou parcial deste trabalho, por qualquer meio convencional ou eletrônico, para fins de estudo e pesquisa, desde que citada a fonte. Para contato com o autor: gabriel.mfernandes@terra.com.br.

F363p Fernandes, Gabriel Fernandes ; orientador Mário Lugarinho. - São Paulo, 2012 .

$94 \mathrm{f}$.

Dissertação (Mestrado) - Faculdade de Filosofia, Letras e Ciências Humanas da Universidade de São Paulo. Departamento de Letras Clássicas e Vernáculas. Área de concentração: Estudos Comparados de Literaturas de Língua Portuguesa.

1. Poesia. 2. Literatura de expressão portuguesa. 3. Literatura africana. I. Lugarinho, Mário, orient. II. Título. 
FERNANDES, Gabriel Madeira. A poética da sinceridade de Rui Knopfli. Dissertação apresentada ao Departamento de Letras Clássicas e Vernáculas da Faculdade de Filosofia, Letras e Ciências Humanas da Universidade de São Paulo para obtenção do título de mestre em Letras. Área de concentração: Estudos Comparados de Literaturas de Língua Portuguesa.

Aprovado em:

Banca Examinadora

Examinador:

Julgamento: Assinatura

Examinador:

Julgamento: Assinatura

Examinador:

Julgamento: Assinatura 
Porque não se escreve, no mar, com grafites ou tintas. No mar, escreve-se apenas com sangue. Gustavo Guiral

Dedico este trabalho àqueles que traçaram comigo a minha história A minha mãe, guerreira.

O meu pai, que pisa firme pra que eu não me perca.

Os irmãos, Henrique e Carlos e as cunhadas Ana Carolina e Bruna Bischoff, com a compreensão que só irmãos podem ter.

Os irmãos mais novos, Isadora e Pedro, que só alimentaram minha alegria com sorrisos e caretas.

Os irmãos que a gente escolhe, Leandro Celestino e Gustavo Henrique Guiral dos Santos, que me ensinaram a escrever no mar.

A professora Elaine Veronesi Fukuda, que me ensinou o valor da escrita E a Carolitcha, é claro. 


\section{AGRADECIMENTOS}

Agradeço aqui às pessoas que acompanharam esse meu trajeto e que souberem me entender:

Cássia Tamura, Bruna Fava, Elizabete Viana, Daniel Zungolo, Monika Kratzer, Selma Correa, Maria Rocha, Luciana Baraldi, Igor Aoki, entre outros que me ensinaram muito sem dizer palavra alguma.

Bárbara Garcia, Beatriz Blanco, Lucas Pantera Torrisi, Lucas Shimoda, Fabiana Muliterno, entre outros que percorreram os corredores da FFLCH de mãos dadas comigo.

Ricardo Bassetto, Leonardo Bassetto, Rafael Lala, Bruno Zelli, Tiago Aparecido dal Aba de Souza, Luciana Castilho entre outros que mantêm o bom-humor não importando a adversidade.

Tania Dias, a chefinha mais incrível que o mundo já conheceu.

Paloma Falcon Cassini, Carina Gotardelo, pela amizade inusitada e tão intensa.

Pra todos vocês guardo sempre um abraço e um sorriso. 
RESUMO

FERNANDES, G. M. A poética da sinceridade de Rui Knopfli. 2012, 95f. Dissertação (Mestrado) - Faculdade de Filosofia, Letras e Ciências Humanas, Universidade de São Paulo, 2012.

Enfatizando a relação que a obra de Rui Knopfli mantém com o espaço africano como portador de experiências vivenciadas pelo poeta, e pelo qual ele nutre um sentimento de pertença bastante intenso, empreendemos a pesquisa. A resistência a uma poesia a serviço de uma ideologia levanta a questão da limitação ideológica da arte em favor de sua causa. Explorando as muitas tentativas do poeta de escrever uma "arte poética", nos deparamos com uma honestidade e fidelidade consigo mesmo que guia o poeta do início ao fim de sua produção poética mesmo lhe custando o afastamento de sua terra natal e espaço de preferência. Reconhecemos o valor de sua poesia como afiliada à tradição ocidental e também a aproximação que promove com os espaços africanos. Assumimos, dessa maneira, a defesa da obra de Rui Knopfli como um dos pilares da poesia moçambicana, o pilar subjetivo, que acreditamos ser a tendência das próximas gerações poéticas em Moçambique.

Palavras-chave: Poesia. Cânone. Moçambique. Rui Knopfli. 


\begin{abstract}
FERNANDES, G. M. A poética da sinceridade de Rui Knopfli. 2012, 95f. Dissertação (Mestrado) - Faculdade de Filosofia, Letras e Ciências Humanas, Universidade de São Paulo, 2012.

Highlighting the relationship of the work of the Rui Knopfli keeps with the African space as a keeper of experiences lived by the poet and for which he feeds a feeling of belonging very intense, we undertook this research. The resistance to a poetry in service of an ideology raises the question about the ideological limitation of art in favor of his case. Exploring the many attempts of the poet to write a "art poetic", we are faced with a honesty and loyalty to himself that guides the poet from the beginning to the end of his poetic production that cost him the departure from him homeland, place of preference. We recognize the value of his poetry as affiliated with the Western tradition and also with the approach that promotes with the African spaces. We assume, thus, to defend the work of Rui Knopfli as a pillar of the poetry of the Mozambique, the subjective pillar, that we believe to be the trend of future generations poetic in Mozambique.
\end{abstract}

Keywords: Poetry. Mozambique. Canon. Rui Knopfli. 
SUMÁRIO

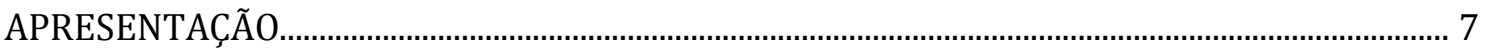

1 UMA CICATRIZ NA HISTÓRIA - A SINCERIDADE DE RUI KNOPFLI ……................................. 9

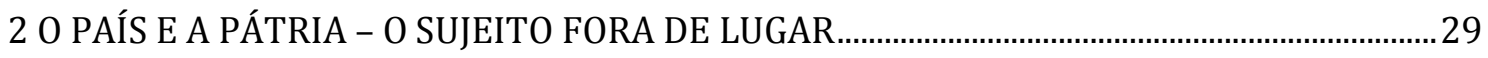

2.1 No meio do caminho: o poeta entre espaços culturais.................................................. 32

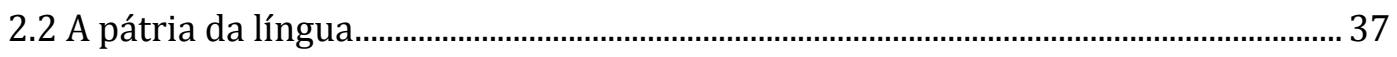

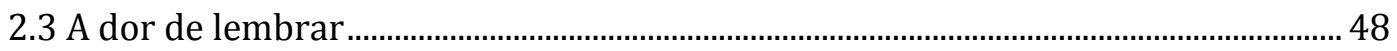

2.4 Knopfli e Craveirinha - O país de quem, afinal? ...............................................................52

3 ARTE POÉTICA - A SINCERIDADE E A FIDELIDADE À PROVA...................................................59

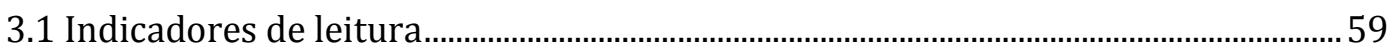

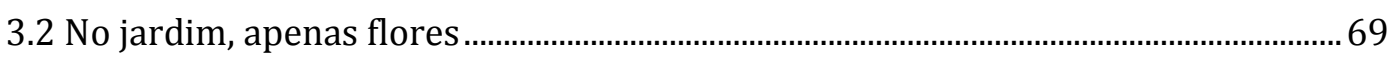

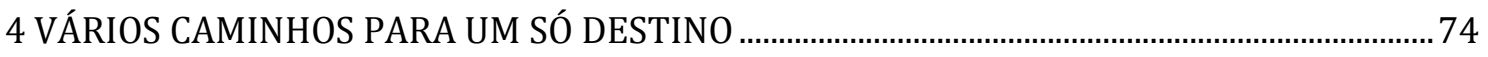

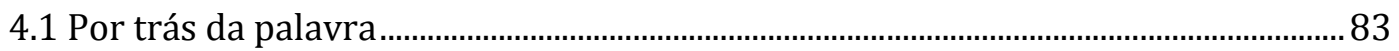

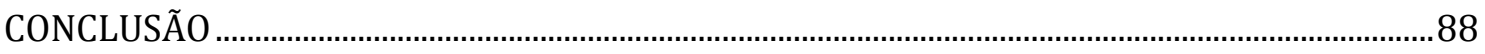

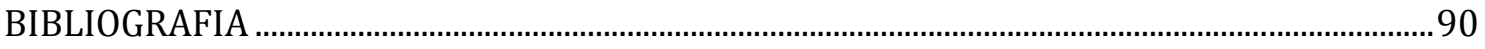




\section{APRESENTAÇÃO}

Ao iniciar o trabalho, jamais imaginei as dificuldades que me ocorreriam ao longo desta dissertação. Foram muitos os percalços ao longo de toda a jornada que deu à luz esta dissertação. Alguns aspectos pessoais me forçaram a ocupar muito do meu tempo com um trabalho externo, dificultando a pesquisa e a dedicação que um trabalho deste porte merece. No entanto, encontrar a poesia de Knopfli foi encontrar, dentro das literaturas africanas de língua portuguesa, algo que fizesse a diferença também na minha vida.

O lugar de enunciação Knopfliano sempre foi muito atrativo pra mim. 0 seu não alinhamento político-ideológico, seu trabalho poético, o modo como lida com a memória e principalmente a qualidade de seus versos me atraíram desde o início para sua obra. Tentei iniciar, ainda na graduação, uma pesquisa sobre ela, mas também por motivos de força maior, acabei não conseguindo.

Lembro-me de me perguntarem, uma porção de vezes, o porquê de eu estudar um poeta moçambicano e, mais especificamente, este poeta. A resposta mais certeira e mais imediata que me ocorria era "porque ele é estranho, um pouco como eu". Esse é um critério muito vago, não? Mas há critério mais válido do que o gosto?

Daí, perguntas imediatamente saltam: por que ler um poeta que se restringe a seu mundo? Em que essa leitura pode afetar-nos? Uma leitura precisa afetar o leitor? 0 que o diferencia de um jovem escrevendo um blog confessional? 0 que Knopfli escreve, portanto, pode ser algo apenas escrito para o "eu" que ele enuncia e nós criamos a aura de que o poema necessita pra se tornar poema, objeto-poema, mercadoria-poema. Diferentemente, por exemplo, do que faz a poesia de cunho ideológico, que visa 
justamente cativar o leitor para que participe de sua causa. E até que ponto essa arte não sacrifica sua potência em favor da abrangência de público? Isto é, uma poesia que lute por uma causa social deve fazer-se legível e inteligível para todos os que estão comprometidos com essa causa? Quem tem a autoridade para nomear como poema uma produção? Atropelando essas questões, ou não lhes dando importância, pode-se negligenciar ou ocultar uma produção literária de qualidade. Os interesses políticos sempre em voga, principalmente numa zona de instabilidade política, como fora Moçambique durante todo o processo de independência e ainda alguns anos depois, podem apoderar-se dessa produção literária para fazer que ela os sirva? E aquela literatura que se faz de forma diferente? Aquela que pensa por outros caminhos, ou que versa sobre outros assuntos que não os de interesse daqueles que comandam? Mesmo com todas as contradições da obra Knopfliana, ou talvez por elas, decidi-me por adentrar a sua obra e me surpreendi com cada descoberta, com cada verso. Essa surpresa é a mesma que eu espero poder demonstrar no estudo que segue. 


\title{
1 UMA CICATRIZ NA HISTÓRIA - A SINCERIDADE DE RUI KNOPFLI
}

\author{
À guisa de introdução
}

Rui Knopfli nasceu em 1932 (em Inhambane, Moçambique) e faleceu em 1997 (em Lisboa, Portugal). Filho de pais portugueses, pai funcionário público e mãe professora, estudou no liceu em Moçambique e completou seus estudos em Johanesburgo, onde conheceu a obra de poetas de língua inglesa que teriam bastante importância em sua própria obra. Além de poeta, também foi jornalista e crítico literário, tendo colaborado com e dirigido alguns periódicos sobre arte. A esse respeito, no Dicionário Cronológico de autores portugueses (1999) em que Knopfli é incluído, sendo, portanto, tratado como português, podemos ler que ele:

Colaborou activamente na imprensa desafecta à administração colonial, casos de A Tribuna - jornal de que viria a ser um polémico director, entre Maio de 1974 e Fevereiro de 1975 - e $A$ Voz de Moçambique. Nos anos sessenta e setenta, respectivamente, co-dirigiu, com Eugénio Lisboa, os suplementos literários destes dois jornais. Lançou, com João Pedro Grabato Dias, os cadernos de poesia Caliban (1971-72), que reuniram colaboradores como Jorge de Sena, Herberto Helder, António Ramos Rosa, Fernando Assis Pacheco, José Craveirinha, Sebastião Alba, etc. Dirigiu o caderno Letras \& Artes (1972-75), da revista Tempo, ali tendo publicado traduções de inúmeros poetas, como, entre outros, T. S. Eliot, Blake, Sylvia Plath, Kavafis, Dylan Thomas, Yeats, Robert Lowell, Pound, René Char, Apollinaire, Octavio Paz e Reverdy. Integrado, como adido de imprensa, na delegação portuguesa à Assembleia-Geral das Nações Unidas, participa em Nova Iorque (1974) dos trabalhos da Comissão de Descolonização.

Knopfli deixa Moçambique em 1975 e vai viver em Londres. Anos mais tarde, em 1982, torna-se conselheiro de imprensa na Embaixada de Portugal. Esses dados 
biográficos serão explorados com mais ênfase durante a análise de sua obra, tendo em vista que esta é marcada intensamente pela experiência do autor, isolado na própria terra, ou mesmo na condição de exilado, quando passa a viver em outro país e continente. (MATUSSE, 1997; LABAN, 1998; CHABAL, 1994)

A obra de Rui Knopfli foi bastante associada às correntes europeias, por conta de sua recorrência às tradições poéticas e culturais ocidentais e metropolitanas e pela falta de uma afirmação de pertença a um espaço nacional-moçambicano enquanto Moçambique atravessava a sua Guerra de Libertação, conflito que culminou com a independência política de Moçambique, até então sob o jugo português. Esse movimento de libertação, como é sabido, gerou um movimento de amor e de valorização da terra, de afirmação das diferenças em relação às metrópoles, de afirmação de uma identidade nacional. Tentava-se criar, no plano ideológico e cultural, uma identidade, uma nação, de um conjunto de etnias que partilhavam o mesmo território. Essa identidade se mostrava necessária pelo discurso político vigente e, tendo em vista que a produção literária e os intelectuais estavam diretamente ligados ao movimento de libertação, seja na forma de guerrilha ou através dos partidos políticos, era natural que algo dessa busca por uma identidade nacional se refletisse na literatura, trazendo à tona a valorização da terra através de uma moçambicanidade.

Durante o período de instabilidade da Guerra de Libertação, com textos muito marcados pelo caráter ideológico e de contestação, outros autores, como José Craveirinha e Noémia de Sousa, tentavam mostrar, principalmente, as diferenças em relação à metrópole: Portugal. Havia a tentativa de valorizar os traços da própria terra. No entanto, essas tentativas esbarravam em alguns obstáculos. A falta de uma tradição comum a todos que partilhavam o território moçambicano fez que as referências às tradições fossem marcadas apenas superficialmente. A ênfase maior, portanto, não poderia ser dada às tradições. 0 que houve efetivamente foi um apelo ao sofrimento partilhado, ao racismo português, aos ancestrais que foram levados contra a vontade para o outro continente. O sofrimento do negro escravo, humilhado e submetido às vontades da metrópole portuguesa gerava um inimigo comum: o colonizador português. Isso sem contar ainda as ideologias de esquerda, como o pensamento socialista, por exemplo. 
Além da diversidade de grupos étnicos que foram circunscritos a um território demarcado por linhas imaginarias, Moçambique recebeu portugueses, indianos e ingleses. Tal diversidade nem sempre é levada em conta na sua totalidade quando da defesa da identidade nacional e da afirmação da diferença em relação à cultura portuguesa. 0 primeiro motivo que podemos elencar para isso é justamente o motivo da busca: uma identidade. Essa identidade não assumiu a forma da diversidade, mas, sim, a de uma unificação, uma unidade de expressão. Assim, podia-se cooptar a maior parte da população sob uma única bandeira, sob um único objetivo. Esse caráter ideológico vem reforçado pelo momento vivido no país, ou seja, pelo movimento de libertação contra os portugueses.

Ainda sobre essa diversidade étnica, Knopfli assume-se como não pertencendo a nenhuma delas. Em um posfácio ao livro A ilha de Próspero, de 1972, o poeta escreve:

Filho de pai alentejano e de mãe serrana, nascido na cidadezinha de Inhambane, o autor não ignora, nem esconde, a sua origem. "pied noir", tal como o cristão não nega o pecado original embora, um e outro e de uma e outra coisa, procurem redimir-se por vias diferenciadas e - crê-se - com total sinceridade.

E eis que o autor, "pied noir" de origem, olha em redor verificando que a expressão Moçambique, no seu cariz abstracto de desinência geo-política, engloba várias nações ou etnias - ronga, chope, chona, maravi, anguni, macua, lomué, ajáua, maconde, etc. - e que ele não tem lugar em nenhuma delas.

Não levei, claro, vinte anos a racionaliza esta perplexidade, mas precisei contudo calcorrear o itinerário que vai de Mompracém o rochedo de Sandokan - à ilha de Próspero, para resolvê-la. (KNOPFLI, 1972, p. 131-132)

Assim, Knopfli assinala que conhece seu lugar, que se sente diferente. Mas também revela que encontrou um meio de "resolver" essa diferença, ou seja, de lidar com ela de um modo proveitoso e harmônico. Suas maiores dificuldades não estão ligadas diretamente ao fato de ele ser um "pied noir", mas em sua postura artística, como veremos mais adiante.

Dentro dessa diversidade, a cultura de língua inglesa também será levada em conta, mas de forma comedida. Principalmente por causa do movimento negro estadunidense, que foi muito expressivo (MATUSSE, 1998). Podemos ver isso claramente nos versos de "Deixa passar o meu povo", de Noémia de Sousa, influenciado por e dialogando com o spiritual "Let my people go". Esta cultura também se apresenta 
como um modelo alternativo ao português, mas houve parca exploração por parte dos escritores moçambicanos. Isso ocorre em oposição, por exemplo, ao que Knopfli faz ao declarar, por exemplo, que a poesia de língua inglesa é a melhor do mundo, em sua perspectiva.

Assumir uma identidade unificadora pra toda essa diversidade tem um preço, como o "apagamento" dessas outras presenças constituintes do povo moçambicano, por exemplo, a presença muçulmana (fenômeno que merece mais atenção e ao qual raros trabalhos foram dedicados). Há somente pinceladas da presença indiana nas obras dos autores daquele contexto, aparecendo mais como paisagem que como personagens efetivos da história da literatura, reproduzindo, portanto, um modelo de literatura praticado pela metrópole, como acontecia aos negros na chamada literatura colonial (escrita por portugueses, na qual o negro somente figurava como personagem secundária, como pano de fundo de seus romances).

Para unir o povo sob um único propósito, portanto, desenvolveu-se um inimigo comum. Assim, além de unir a população, reavivava-se a ideia do sofrimento partilhado por todos, originando, consequentemente, um inimigo comum. Isso trazia grandes vantagens políticas e ideológicas que supria os interesses dos que comandavam o movimento de libertação nacional naquele momento. Dessa forma, obtinham o apoio popular e geravam um sentimento de pertença à terra, a Moçambique, de valorização do território delimitado como Moçambique, fazendo acreditar que ali todos tinham, se não uma origem, um sofrimento e um futuro comum quando libertos do jugo português e marcando uma relação antagônica entre a administração colonial e aquilo que estava por vir, a nação que surgia e que, futuramente, adotaria o regime socialista.

A desconsideração da diversidade étnica e, portanto, cultural trouxe alguns problemas. A ideia de modernidade, por exemplo, que passava sempre pela suposição de que ser moderno constituía um avanço econômico e científico, mas essa mesma modernidade não encontrava respaldo nas sociedades em que o movimento revolucionário não estivesse presente de forma intensa, onde se mantinham, portanto, relações mais tradicionais. 0 plano de criação da identidade nacional, com o engajamento político e bélico da população durante a revolução funcionava bem no front. Contudo, onde o povo lidava diretamente com a administração colonial, arraigada já em suas estruturas, os modelos organizacionais se formulavam como reprodutores 
desse sistema colonial, ainda que em oposição a ele, ou como a tentativa de retomada da organização tradicional. Assim, desconsiderou-se ou subestimou-se o fato de que

"a construção da unidade nacional” se fazia em estreita interação, sempre conflitual, com identidades já existentes, as quais, na resistência cultural ao colonialismo, tinham desenvolvido mecanismos de defesa e iniciado processos de adequação de seus valores e de seus sistemas simbólicos ao diálogo com a "modernidade. Condicionado pela bipolaridade da guerra, o movimento de libertação viu nos potenciais "espaços intersticiais" (BABHA, 2001, p. 22) que se esboçavam no fim da ocupação estrangeira uma "contaminação" colonial, e não uma janela que se abria sobre a apropriação de formas de "modernidade". (CABAÇO, 2008, p. 310).

Outro equívoco do movimento revolucionário foi pensar que uma vez assumido o compromisso nacional, essa identidade criada seria irreversível, no entanto

Se é certo que o "sentimento de pertença a uma entidade chamada Moçambique foi assumido por amplos estratos da população, o fim da situação de guerra e a independência viriam a provar quão frágil era, em contrapartida, a assunção de uma "identidade nacional." (CABAÇO, 2008, p. 310)

Assim, a literatura engajada na luta libertária tinha como função principal a criação dessa unidade identitária, ou seja, tentar apagar ou enfraquecer as particularidades de cada etnia em favor do surgimento de um povo unificado sob a mesma bandeira. Mas essa tentativa conseguiu, na verdade, unir o povo contra uma mesma bandeira, a portuguesa, a do sistema colonial. Apesar disso, o que queremos ressaltar é o contexto pelo que passava Moçambique e ao qual Knopfli não se alinhava. Claro é que ele também não estava apoiando o sistema colonial, mas preferiu antes de pensar esse conflito e todas as suas contradições, recolher-se a si próprio e pensar a sua relação com o mundo que o circundava, antes disso, resolveu criar um mundo para a existência de sua poesia, tendo em vista que os conflitos revolucionários estavam tentando justamente diluir as individualidades no projeto de construção da identidade nacional.

Cabe lembrar que a literatura moçambicana não apresenta uma unidade como a da literatura angolana dentro do cenário das Literaturas Africanas de Língua Portuguesa. 0 aspecto fragmentário se dá de várias formas, desde o ponto étnico- 
linguístico até o político-econômico. Dessa forma, tem de se levar em conta essa fragmentação nesse momento de formação e mesmo posteriormente, quando a literatura começou a ganhar corpo com uma história literária, mas cuja fragmentação será uma das características principais.

A literatura contribuiu muito para essa construção da identidade e para tentativa de unificar o povo sob um mesmo propósito de uma forma bastante singular. Não foi meramente uma produção que se deu por conta do conflito ideológico e bélico travado em território africano, mas também foi material de divulgação de ideais libertários, a literatura estava no front.

Esses fatores forçam a eleição de um cânone entre os poetas que representam a nação moçambicana como objeto de identificação, movidos pelo momento em que estão. 0 contexto político atua, portanto, como organizador desse cânone, como o que decide entre o que de fato pode ser escrito e o que não pode, quais temas podem ser abordados e como, o que representa a nação e o que não representa. 0 problema é que nem sempre o que não representa a nação está contra ela.

0 movimento libertário também sofreu com um círculo vicioso. Criou-se (ou copiou-se, na medida em que, mesmo respeitando as particularidades moçambicanas na adoção do modelo marxista-leninista, ainda se tratava de um modelo exógeno?) um modelo ideológico a ser seguido, pregaram-no através das artes, em particular através da literatura, que também ajudou a construí-lo e que passou a não ser reconhecida sem esse componente ideológico. Mas em tudo isso a literatura parece ainda ganhar um ponto a seu favor, acima dessa disputa acirrada (e eterna?) entre arte e ideologia: na linguagem; justamente a linguagem, ou a sua distorção, a sua desautomatização é o que a literatura nos proporciona. Assim, entra em jogo o valor da oobra, por exemplo, de um José Craveirinha, que trabalha muito bem a linguagem, se valendo não apenas da ideologia que defende, e não escrevendo apenas sob essa bandeira (tendo escrito também poemas líricos e eróticos). Essa dimensão é quase sempre contornada pela crítica que se atém aos aspectos ideológicos para satisfazer a demanda por tal crítica, imposta não só pelo momento, mas por aqueles que darão sequência a ele, fascinados pelo histórico de luta pela libertação do Estado moçambicano sob a bandeira vermelha do socialismo. Assim, o que de melhor essa literatura oferece comungando um jeito de pensar, de ser, em determinadas línguas (lembrando a multiplicidade de línguas que 
habitam Moçambique) em uma única língua que lhes foi imposta pelo colonizador português, subvertendo-a, unindo a ela termos de suas culturas (lembrando também a multiplicidade cultural das etnias moçambicanas) e atribuindo novos significados a palavras próprias da língua portuguesa, tudo isso, foi atropelado em busca de uma ideologia unificadora. Ou, ainda, quando se deu valor a esse tipo de criação, vinculou-se sempre e imediatamente à afirmação da diferença em relação aos portugueses. Essa ideologia estava sim presente, não podemos nos enganar, mas ela tem sido vista como único ponto forte da literatura produzida nesse contexto.

A poesia de Knopfli, por sua vez, nada a braçadas largas em um sentido diferente da ideologia pregada por seus contemporâneos. Trabalha muito mais a linguagem, o fazer poético, tentando não se haver com a instabilidade política do momento. Vai defender a ideia de que essa não é uma luta sua, uma luta que ele deva lutar. Ele vai ao encontro das metrópoles no que diz respeito a suas leituras, principalmente as de língua inglesa, influenciadas diretamente por seus estudos em Johanesburgo, na África do Sul. O próprio Knopfli diz:

A descoberta do Eliot foi uma descoberta sensacional e foi uma influência enorme. Creio que serei o único caso [em Moçambique] em que há uma influência da poesia inglesa. A grande punhalada foi o Eliot. Mas desde o John Donne... Para mim, a poesia inglesa é a melhor do mundo. A gente pega no William Blake, no Wordsworth... eu abri-me muito para ela quando estive em Johanesburg. (CHABAL apud MONTEIRO, 2003, p. 30)

Não vamos adentrar o conceito de influência levantado por Knopfli, mas reconhecemos o peso dessas leituras em sua obra e na sua formação enquanto poeta. Isso destaca também as leituras e as preferências literárias de Knopfli.

No entanto, a despeito dessas afirmações quanto a suas preferências literárias ou culturais, o poeta sempre afirma um sentimento de ser africano que passou, aparentemente, despercebido pelas primeiras leituras de sua obra. Essas duas forças, aparentemente opostas, estão presentes em várias dimensões de sua obra. No entanto, Knopfli, no que diz sobre sua obra, parece cair, muitas vezes em contradição. Como se sabe, há um espaço enorme entre o que se diz e o que se quis dizer, ainda mais quando estamos no âmbito da poesia, onde a presença do leitor é fundamental, ou seja, onde o leitor determinará que leitura fará. 
Objeto magnético, secreto sitio de encuentro de muchas fuerzas contrarias, gracias al poema podemos acceder a la experiencia poética. El poema es una posibilidad abierta a todos los hombres, cualquiera que sea su temperamento, su ánimo o su disposición. Ahora bien, el poema no es sino eso: posibilidad, algo que sólo se anima al contacto de un lector o de un oyente. Hay una nota común a todos los poemas, sin la cual no serían nunca poesía: la participación. Cada vez que el lector revive de veras el poema, accede a un estado que podemos llamar poético. La experiencia puede adoptar esta o aquella forma, pero es siempre un ir más allá de sí, un romper los muros temporales, para ser otro. Como la creación poética, la experiencia del poema se da en la historia, es historia y, al mismo tiempo, niega a la historia. (OCTAVIO PAZ, 1997, p. 25)

Assim, negando e sendo história, a poesia de Knopfli se constrói. Na mesma medida em que se vai inscrevendo na história, Knopfli tem certeza de seu desaparecimento. Ele deixa pra trás somente seus versos. Essa perspectiva se acentua em seus dois últimos livros, o último lançado no ano de sua morte.

Diante disso, tentaram apagar a obra de Knopfli da história de Moçambique, pelo menos durante os anos mais conflituosos. Depois, mais precisamente em 1989, Knopfli foi convidado a fazer uma comunicação à Associação dos Escritores Moçambicanos. Parece-nos que esse convite se insere em um movimento que resgata a subjetividade, a lírica desse momento pós-independência em Moçambique. Esse movimento parece tomar conta das literaturas africanas de língua portuguesa como um todo. Ela começa a substituir o tom épico da produção anterior. No entanto:

o nítido tom épico das manifestações poéticas do período de luta e descolonização não era mera recorrência programática de uma literatura engajada. Sabe-se que a ancestralidade e o senso de coletividade são dados fundamentais que regem essa subjetividade. 0 sujeito africano, ao contrário do sujeito ocidental, tem condições de reconhecer o seu lugar na cadeia de tradições ancestrais e, dessa maneira, estabelecer uma síntese temporal que, ao mesmo tempo, o integra na série histórica e o desloca para o mito. Entretanto, há manifestações poéticas que, se não escapam dessa herança ancestral, (re)significam a tradição a partir de novas possibilidades subjetivas. (LUGARINHO, 2003, p. 315)

Essa foi a dimensão ignorada por Knopfli. A sua relação com Moçambique é sempre repleta de experiência, mas como ele mesmo diz, as suas vivências culturais não 
são dali. Portanto, ele não foi capaz de identificar nessa poesia de cunho coletivo os componentes culturais ali imersos e conjugados com os ideológicos. Essa falta talvez não seja menor do que o da própria crítica que o deixou de lado pela sua tentativa de isenção da defesa da nação. Assim, mais adiante, discorreremos sobre a defesa que Knopfli faz de sua obra, mas este aspecto não pode ser ignorado justamente por ser constituinte da obra Knopfliana. Diante da impossibilidade de Knopfli reconhecer este componente cultural, ele ataca o sujeito coletivo, não tanto em favor de si, mas em favor da sua própria poesia. Enfatiza muito a diferença entre a sua poesia e a de cunho ideológico, marcando a sua obra não como algo que vai contra esse movimento de afirmação, mas como algo que vem em outra direção, não oposta, apenas diferente. Assim, quando a crítica inicia um movimento de valorização da poesia subjetiva, lírica, começando a abandonar a poesia de mais social e épica, acaba tropeçando em Rui Knopfli. O que fazer com a sua obra? Onde é possível alocá-la?

Essas questões são muito complexas, tendo em vista o lugar de enunciação de Knopfli. Partimos, portanto, para uma defesa de sua obra nos tempos mais difíceis, ou seja, durante o período em que as literaturas engajadas ideologicamente dominavam o cenário literário por conta do contexto político vivido por Moçambique à época. Não fechamos os olhos ao que a obra nos apresenta como problemático, mas, antes, afirmamos esses problemas como constituintes do sujeito e da obra que o sujeito faz, tendo em vista seu não alinhamento político e, por que não dizer, cultural. Afinal, o que se estava afirmando em África nessa época não era justamente as diferenças em relação ao seu colonizador? Knopfli faz a mesma coisa, só por outros meios.

Ao afirmar-se, portanto, diferente, Knopfli não vai contra esse movimento. Esse é o principal ponto de sua obra. Sua obra não se alinha, não adota o sujeito coletivo, seja ele o da cultura africana que destacamos anteriormente, seja ele o do movimento ideológico socialista que se vivia fortemente à época. Ele erra em não reconhecer o componente cultural, não podemos deixar de ressaltar, mas o seu desalinho ideológico também foi tomado, a princípio, como uma afronta ao movimento libertário, isto é, quem não está a favor desse movimento, está, portanto, contra ele. Knopfli, apesar de incorrer em outros equívocos quando o faz, demonstra que não era a favor do sistema colonial. Não apoia essa ideia. Deixa transparecer que também não é um elemento preso à terra em sua essência. Afinal, as vivências culturais do poeta não coincidem com as 
experiências em território africano. Esse paradoxo do sujeito, de estar em uma terra que é a sua, pela qual ele nutre um sentimento muito forte de pertença, mas também um espaço onde as vivências culturais locais não foram experienciadas e que, portanto, não o aceita como um dos seus é a grande riqueza de sua obra. Essa confusão surge ao se tentar classificar a obra de Knopfli e é justamente por conta da falta de precisão nos conceitos que atribuem a nacionalidade literária a um escritor que ela se intensifica.

Para Knopfli, a nacionalidade literária é "um fato, não um decreto". Dessa forma, nascido e criado, portanto, em Moçambique, ele é e sempre será, no seu próprio entendimento, Moçambicano, a despeito de suas vivências culturais. Não acreditamos que esses sejam fatores suficientemente fortes para atribuir a nacionalidade literária a um poeta, mas quais seriam eles? Somente ter nascido em algum lugar? Somente escrever sobre algum lugar? Apenas declarar amor a um lugar?

De qualquer maneira, não temos respostas a essas perguntas e não buscamos respondê-las nesse estudo, mas podemos entrever nos versos de Knopfli, sempre, uma relação forte com a terra, com o espaço moçambicano, ao que ele vai chamar de africano, mas com um pouco de atenção, veremos que chamar-se a si próprio de africano, como ele o faz, é também um modo de generalizar-se e contestar a nação em seus versos. Ele não busca ir contra o estabelecimento de uma nação, motivo da Guerra de Libertação em Moçambique, ele apenas não se alinha ideologicamente ao nenhum dos lados dessa guerra. Knopfli resistia a isso não delimitando em seus versos as mesmas linhas imaginárias coincidentes às fronteiras políticas de Moçambique. Ele, assim, retirava-se dessa luta, não se alinhava a ela, e cantava a sua própria experiência naquele espaço. Uma experiência marcada pelo seu ocidentalismo, pela sua subjetividade exacerbada e por um tom crepuscular.

Essa resistência faz parte de seu plano de fidelidade à obra e à experiência, respaldando uma na outra, de forma a tentar sempre criar algo que, vindo desses dois elementos, não sejam já nem um, nem outro, mas algo que os exceda.

Compreender a obra de Knopfli é compreender a obra e o percurso pessoal de um sujeito fora de lugar. O próprio Knopfli se vale muito d'A Tempestade, de Shakespeare, principalmente no que tange à situação de Próspero como colonizador da ilha de Caliban. Inclusive, um de seus livros chama-se A Ilha de Próspero, de 1972, e é repleto de fotografias ilustradas com alguns poemas. A inversão das posições aqui, em 
que as palavras é que ilustram a imagem não é apenas um recurso retórico, mas o livro é uma grande homenagem à Ilha de Moçambique, as fotografias buscam ilustrar um pouco do fascínio que move Knopfli em sua escrita e, ainda, como veremos no estudo sobre a arte poética de Knopfli, procuram dar ao poema e às fotografias uma unidade que os eleve a algo maior que fotografias e poemas. Uma amálgama, uma relação de simbiose. Nessa ilha, o poeta vê uma relação mais próxima com a terra de Caliban. Mas principalmente por ser a Ilha de Moçambique um território dos mais variados etnicamente e ponto importante da história tanto de Moçambique como de Portugal, ou seja, de suas origens mais próximas.

Rui Knopfli lida, portanto, com todas as suas "armas" na guerra que trava para tentar salvaguardar sua obra do advento do coletivo. Uma dessas armas é a sua biblioteca e as relações que ele próprio mantém com ela. Essa sua biblioteca o acompanha em toda a obra de forma evidente e que o próprio poeta faz questão de deixar claro em alguns poemas e em observações que faz. Fruto, portanto, de uma geração fragmentada numa terra que não vive a sua própria experiência solitária e subjetiva por ter sido criado em um ambiente cultural diverso do de Moçambique, Knopfli explora essa diferença, mesmo que sem o saber, por vezes. A subjetividade que será, posteriormente, retomada, pensando agora no movimento que as literaturas africanas de língua portuguesa desenham no tempo. Após a conquista da liberdade, arrefece a força da literatura de cunho ideológico, podemos ver os filhos dessa revolução, ou a escrita que visa retratar o que aconteceu depois da revolução. Na sequência, a afirmação de subjetividade diante desse coletivo que se impôs como nação a todos após o movimento libertário, ainda que venha, como já mencionamos, marcar o aspecto cultural da coletividade, os escritores começam a olhar para dentro, para ver o que restou em si após a revolução. Como dissemos, é estudando esse movimento que encontramos Knopfli como um dos pilares dessa poesia subjetiva em Moçambique.

Com tudo isso tendo parte importante em sua formação, Knopfli não poderia deixar de ser um continuador da cultura europeia em África, correto? Pois é justamente aí que julgamos ocorrer o maior erro da crítica. Knopfli se vale sim de muitos dos elementos dos espaços culturais dominantes, não africanos, e ocidentais. Ele também entrou em contato com alguns elementos culturais orientais, como podemos ver em seu O livro melancólico de Tao Li, adendo a O escriba acocorado, de 1978. No entanto, ele 
promoveu também uma aproximação entre essas referências e as referências africanas, aproximando esses dois espaços culturais. Por vezes uma aproximação genial, como no poema "Hidrografia”, às vezes, nem tanto. Caso fosse apenas um continuador da poesia ocidental, acreditamos que não haveria tanta intriga ao redor de seu nome, porque o próprio Knopfli certamente não o negaria. Não procuraria se afirmar africano. 0 elemento essencial de sua poesia é certa sinceridade com a qual o poeta trata o seu leitor, a sua obra e a si mesmo. Recusando-se a aceitar aquilo que não lhe é próprio, aquilo em que não acredita, ele nos vai mostrando quem é, com a certeza de que deixava pra trás apenas seus versos. A sua relação com o território moçambicano é intensa, mas sua relação com a língua é maior. E quando falamos em Literatura, a língua tem alguma importância.

Trabalhando, portanto, muito mais a linguagem, num estilo duro, com palavras difíceis, recorrendo abertamente ao dicionário para buscar apurar seus versos, para buscar a palavra precisa, aquela que dará ao poema o tom exato do que se busca dizer, Knopfli escreve para resistir. Escreve à sombra do movimento revolucionário moçambicano, e à sombra porque se apequenava diante do tamanho e da quantidade da literatura produzida no e pelo movimento. Porém sempre consciente dessa pequenez. Knopfli assume o egoísmo que é falar de si e de sua experiência e assume o fato de não saber fazer diferente por ter escolhido ser fiel a um caminho. Em entrevistas e comunicados que fez, sempre assumiu essa fidelidade, e também em sua obra.

Por meio de sua obra, Knopfli traz um aspecto muito interessante. Ele próprio designa como deve ser lido. Ele traça artes poéticas de forma a nos mostrar como escreve e, nesse processo, nos mostra o desejo que como quer que seus versos soem ao leitor. Esse é um fator único na poesia Moçambicana e para o qual pouco valor se tem dado. Nesse processo, Knopfli cria um mundo, cria uma nova realidade para a leitura de seus versos.

Essa ponte que Knopfli constrói para colocar-se no mundo é evocada também, muitas vezes, sob a imagem shakespeariana de Próspero e Caliban, ou seja, retomando e ressignificando a relação entre autóctone e conquistador, ou, no seu caso, entre colonizador e colonizado. A retomada dessa imagem traz consigo a compreensão de sua posição, marcando mais uma vez a consciência do poeta com relação ao seu lugar de enunciação. Assim, o poeta tenta assumir a sua posição na história colonial de maneira 
mais direta. Procura sempre mostrar, em seu desalinho, que não pode assumir a dor e o sofrimento alheio, do qual ele não partilha, mas também não pode apoiar o sistema de domínio empregado por Portugal em suas colônias por ter sua experiência ligada diretamente àquele espaço. Assim, fidelizando-se apenas a si mesmo, Knopfli não terá sua poesia usada em favor de nenhum dos dois lados, senão em favor de si mesmo.

Mal compreendido pela crítica ou com a validade de seus versos, enquanto pertencendo à poesia africana, posta em xeque, Knopfli não parar de escrever. Ele também não deixa de reconhecer o valor da poesia daqueles que trazem consigo o engajamento político-ideológico mais acirrado, isto é, reconhece-lhes a causa, não está alheio à situação desses outros poetas, mas não abraça essa causa, se recusa a ir por aí, como nos vai dizer em seu "'Cântico Negro'”, poema no qual vai buscar em José Régio a referência do não alinhamento.

Toda essa introdução pode parecer um pouco vaga sem a ilustração dessas situações com os poemas mais representativos de sua obra. No entanto, se faz necessária para sabermos o que encontraremos afinal na obra de Knopfli. Não se trata de um mapa de leitura, mas para compreendermos a sua obra, teremos de lê-la sempre atentando a esses aspectos circundantes. Knopfli escreve na história e é, a princípio, por ela derrotado. Por conta da História, é obrigado a deixar a sua terra, embora dizer "sua terra" aqui implique uma reflexão densa na obra knopfliana. Mas é também na história que Knopfli deixa a sua marca. A obra de Rui Knopfli é uma cicatriz na história de Moçambique.

Na impossibilidade de classificá-lo, nos tempos duros da revolução libertária, como poeta moçambicano, a ascendência portuguesa de Knopfli lhe valeu o título de poeta português. Contudo, mesmo em Portugal ele não era de todo aceito, senão de forma marginal. Não era de se estranhar que o poeta, na impossibilidade de habitar como se fora a sua a terra de seus ancestrais e sendo negada a sua terra de escolha, escolhesse a língua como pátria, como território, como um espaço privilegiado pelo qual se move. Seguindo, portanto, o exemplo de Fernando Pessoa, e também respaldado em Jorge de Sena, como lemos na epígrafe a Ilha de Próspero:

Eu sou mesmo a minha pátria. A pátria de que escrevo é a língua em que por acaso de gerações nasci (...) 
Cabe lembrar que o livro no qual se insere a epígrafe supracitada é também uma homenagem à Ilha de Moçambique. Oras, se numa homenagem ao espaço de preferência de poeta lemos que a sua pátria é a língua, ou seja, que naquele espaço não existe uma pátria, o poeta, como fará outras vezes com outros elementos, está nos mostrando que não assumir a pátria é uma resistência. É não se alinhar ao discurso político (e literário?) da época.

Nessa batalha incessante pelo direito de habitar a terra que escolheu, o poeta adota, como campo de batalha, a poesia e faz dela sua pátria, não por discordar dos ideais daquela nação que se preparava pra eclodir, mas por não acreditar que aquela pátria o representaria em sua essência. Isso faz parte da cultura individualista ocidental, na qual se insere a obra de Knopfli. Ele orienta-se por um caminho diferente e escreve sempre em oposição, ou melhor, em diferenciação aos seus contemporâneos moçambicanos, que têm na pátria, no estabelecimento da união dos povos moçambicanos para formar uma nação, o seu objetivo. E é nesse ponto que queremos marcar a maior diferença. A obra de Knopfli não busca objetivo senão o de permanecer. Knopfli mesmo assume que não pode permanecer mais que seus versos, desde seu primeiro livro (O país dos outros, de 1959), em que nos diz: "morri sim, que não me repito,/ mas que ecoo inteiro na força do meu grito" (p. 46).

As obras de seus contemporâneos, servindo, portanto, a um propósito, o da libertação nacional do jugo colonizador português, tem de sempre buscar cativar o leitor. A participação do leitor é, dessa forma, direcionada no sentido de assumir o mesmo ideal daquele que escreve, tem sempre uma finalidade. A poesia de Knopfli, no entanto, não busca mais que satisfazer o próprio sujeito que escreve. Egoisticamente, o poeta busca não mais que a si mesmo, objetiva-se se projetando como futuro leitor de sua obra, como no seguinte poema:

\section{O ESCRIBA ACOCORADO}

Sentado na Pedra de ti próprio, não tens rosto, senão o que, de anónimo, a ela afeiçoou a mão que assim te quis. Do resto, do que de individualidade, porventura, em ti existiria, se encarregou a persistente erosão dos dias. De vago, 


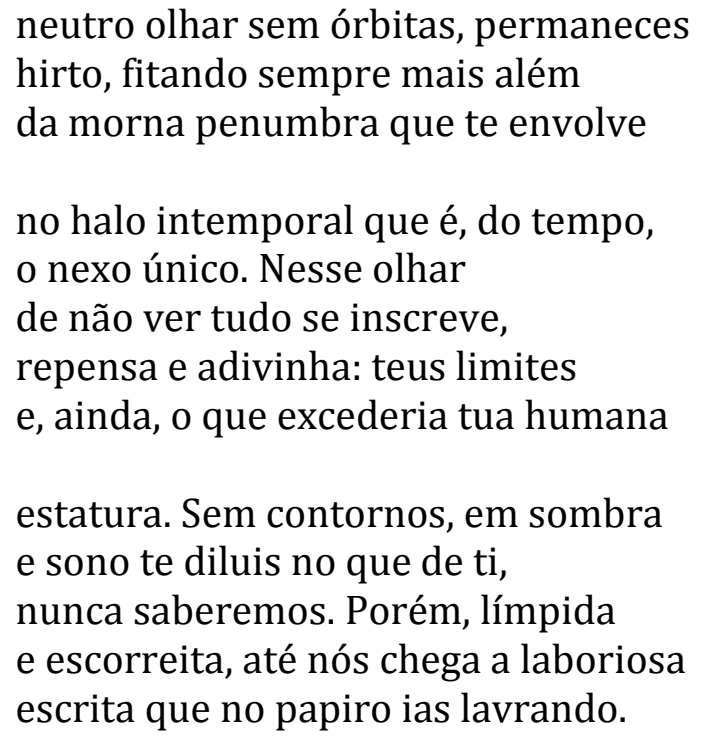

Projetando no escriba a imagem que imagina pra si, Knopfli se vê como leitor e reprodutor desse modelo de sobrevivência, de permanência através de sua obra. 0 sujeito apaga-se, será, fatalmente, vencido pelo tempo, mas através de seu trabalho, de sua obra, deixa como herança de seu tempo e de sua existência algo que lhe excede a estatura, que é maior que ele próprio, no caso do escriba, "a laboriosa escrita", coincidentemente, Knopfli também deixa atrás de si uma escrita trabalhada, mudando apenas o suporte, do papiro para o livro, mas que também partilham as mesmas finalidades, a da divulgação, a da permanência, a de resistência ao tempo.

Como tudo isso é sempre voltado à sua experiência, às suas referências, o poeta não se sente no direito de incluir mais que a si próprio em seus versos. Ele assume o compromisso apenas consigo próprio, numa poesia egocêntrica, egoísta.

O melhor ainda, o mais velhinho e garantido é começar [o poema] pela palavra eu. Será umbicalista, egoísta, eu sei cá, mas é pequenina e humilde e não diz mais do que diz, não tem mais responsabilidades do que as que convém seu minúsculo e modesto universo.

(“Ars poética 63”, p. 191)

0 poeta, dessa maneira, não quer as reponsabilidades implicadas em assumir um sujeito coletivo em favor de um ideal. Como já destacamos, Knopfli parece não reconhecer o componente cultural que dá maior força ao discurso africano que mesmo 
quando se enuncia em primeira pessoa, se objetiva em função de uma coletividade (LUGARINHO, 2003). Ainda respeitando esse não conhecimento, seja por conta de sua ascendência e criação à portuguesa, seja por conta de sua formação fora de Moçambique, mais especificamente em Johanesburgo, o poeta se vale, no trecho citado, do mesmo recurso, mas em favor de si próprio, ou seja, em favor de um "eu". Essa responsabilidade, o próprio poeta nos vai dizer, que não é sua, pelo menos não no campo na poesia. Ele não busca se eximir do seu contexto, mas busca a plenitude daquilo que diz e não quer "fingir" aquilo que ele não viveu. A característica principal de seus versos é a sua honestidade, a fidelidade a uma profissão de fé que o poeta faz em não colocar na em verso aquilo que fuja à sua apreensão enquanto sujeito empírico, isto é, aquilo que tenha sido vivenciado por ele. Assim, ele nos vai dizer: "Como é que eu posso fingir em verso o negro humilhado que não sou".

Assumindo esse compromisso apenas consigo mesmo, Knopfli sabe de sua condição, no mínimo, marginal no contexto das produções poéticas que se faziam à época. Assim, não se sente no direito de assumir essa posição ideológica e fala apenas a partir de sua perspectiva, a partir de sua experiência. Esta mesma experiência que não busca cativar ninguém, não busca a comoção alheia ou a cooptação ideológica, nem sequer busca despertar aos olhos do leitor a vocação para militar em favor de um direito ou ideal. Diz o poeta, em "'Cântico negro'”:

\section{(...) Sou só.}

Não parcialmente, mas rigorosamente só, anomalia desértica em plena leiva. Não entro na forma, não acerto o passo, não submeto a dureza agreste do que escrevo ao sabor da maioria. Prefiro as minorias. De alguns. De poucos. De um só se necessário for.

Assim, o poeta se retira de um "conflito" no qual ele acredita que não deve lutar. Quando o poeta pergunta, no já citado "Ars poética 63": "Pra quê/ querer incendiar os astros se, dentro de nós,/ ainda não acendemos todas as luzes?"; ele busca mostrar que esse é o caminho que ele persegue, a iluminação própria, egoísta e que não diz respeito a mais ninguém que não a ele próprio. Isso se dá porque o poeta trás a certeza de que será esquecido e que apenas os versos se lhe seguirão, como podemos ver, por exemplo, nos versos que seguem: 


\section{POSTERIDADE}

Um dia eu, que passei metade da vida voando como passageiro, tomarei lugar na carlinga

de um monitor ligeiro e subirei alto, bem alto, até desaparecer para além da última nuvem. Os jornais dirão:

Cansado da terra poeta fugiu para o céu. E não voltarei de facto. Serei lembrado instantes por minha família, meus amigos, alguma mulher que amei verdadeiramente e meus trinta leitores. Então meu nome começará aparecendo nas selectas e para tédio de mestres e meninos, far-se-ão edições escolares de meus livros. Nessa altura estarei esquecido.

A certeza do desaparecimento de si, característica que atravessa toda a sua obra, faz dá ao poema um ar de eternidade, onde o poeta também se projeta, mas onde não poderá ser jamais eterno. $\mathrm{O}$ homem por trás dos versos será fatalmente esquecido. $\mathrm{E}$ é justamente esse homem que sempre se traduz nos versos que buscamos trazer à luz, para, como ele faz em seus versos, possamos promover a mesma relação simbiótica entre a sua biografia e a sua obra, gerando uma leitura mais abrangente e mais profunda que se lêssemos apenas a obra ou a biografia, mas tomando muito cuidado com as limitações que uma leitura biografizante pode trazer à compreensão da obra de Knopfli.

A sinceridade dos seus versos contrastada aos seus contemporâneos não, afinal oposta. A oposição nesse ponto se dilui. Em outros tantos, ela se afirma e impõe de maneira muito marcante. Mas nesse em particular, os poetas que visam cativar o leitor, que escrevem uma poesia carregada de ideologia revolucionária são tão honestos e sinceros quanto Knopfli em sua busca intimista e egoísta de si próprio, se uma "iluminação" própria.

A busca incessante que Knopfli empreende por uma "arte poética" que o represente reflete um pouco dessas tentativas de ser honesto consigo mesmo. É através delas também que o poeta nos mostra os caminhos para adentrar a sua obra, ele delimita a própria leitura na medida em que expande as possibilidades de identificação 
com a subjetividade ali estampada. Mas isso apreensível por ser um elemento da cultura ocidental do qual partilhamos, ou seja, quanto mais subjetiva a poesia se faz, ela parece tornar-se mais universal.

A obra de Knopfli também não se restringe somente à subjetividade. Esse é o seu elemento principal, mas também se inscreve na história, deixando, como dissemos, uma cicatriz. A cicatriz fica por conta da falta de lugar para destinar a poesia de Knopfli e pelo seu conteúdo diferenciado do período em que o tom revolucionário tomava conta de todos os versos produzidos. Mas também em função desse tom revolucionário Knopfli vai afirmar o seu desalinho, também em função da produção poética de cunho coletivizante Knopfli vai afirmar o seu egoísmo, em função do estabelecimento da nação moçambicana, fruto do movimento revolucionário em que a literatura teve um papel importante na divulgação de ideais e na construção de uma identidade nacional que unificasse os povos que partilhavam as fronteiras moçambicanas, Knopfli vai afirmar "pátria é só a língua em que me digo". Assim, afirmando-se diferente de tudo o que o cerca, mas também inserido nesse mesmo contexto, o poeta nega a história que o cerca para reescrevê-la a seu modo, mas sempre em função daquela primeira.

Esses argumentos são os de que se vale a obra knopfliana para afirmar-se em um período em que seus versos eram questionados quanto à sua validade. Tomado como um discurso pequeno burguês e, portanto, contrário aos ideais da nação, as primeiras leituras de Knopfli sequer a ele atribuíam a nacionalidade Moçambicana, apontando-o como mero reprodutor de uma poesia europeia em território africano e que não se envolvia nas questões cruciais do país. Acreditamos que isso está em sua obra, ou seja, esses aspectos podem ser depreendidos dela, mas ao estudarmos a vida de Knopfli, poderemos ver que isso dará um tom muito próximo do que acontece em suas artes poéticas. A sua vida mistura-se à obra de forma simbiótica, gerando algo que excede o poeta e também a obra. Em quase todos os aspectos da sua obra essa relação se faz notar. Já citamos as fotos e os poemas em um de seus livros, isso também ocorrerá nas suas tentativas de arte poética. A ideia de que somando "um" e "um" não teremos como resultado "dois", teremos, pois, outro "um" diferente dos dois "um" anteriormente somados.

É conjugando todos esses fatores que a obra de Knopfli vai se desenhar. Em meio a um contexto bastante adverso no cenário literário, a sua obra se faz contra tudo e 
contra todos. Mais que isso, não é exatamente "contra" o seu contexto que ele escreve, mas ele escolhe um caminho diferente a seguir diante dele. Essa escolha implica coragem para seguir adiante tendo como guia nada mais que a fidelidade que sua obra reiterará diversas vezes, tendo consigo apenas o amor das palavras e a certeza do esquecimento. Um dos problemas na crítica que se faz à obra de Knopfli é que todas as palavras usadas na comparação entre sua obra e a de outros poetas contemporâneos seus, principalmente com a de José Craveirinha, por ser o maior expoente de outro tipo de poesia, Trazem consigo a ideia de oposição. 0 que vamos propor em outra parte desse estudo é uma aproximação das obras, não para diluir as diferenças, tampouco para torná-las inconciliáveis, mas para que a comparação possa se dar sem a ideia préconcebida em favor de um ou de outro poeta, mas aceitando as diferenças e entendendo as semelhanças. Esse processo parece mais difícil quando temos em mente palavras como contraste, oposição, confrontar, entre outras utilizadas quando comparamos a obra desses dois poetas e que têm em sua origem a ideia de contrariedade, de que um vai contra o outro, como não acontece com a obra de Knopfli.

Desvestindo-nos, portanto, desses rótulos que põem Knopfli sempre em oposição a algum pensamento ideológico, assumimos como análise os argumentos que o próprio poeta nos deu, naquela já citada ponte que ele constrói com seus versos para inserir-se no mundo, ou para criar um mundo em que seja possível a existência de seus versos a despeito do que podem dizer moçambicanos ou portugueses. Assume o espaço africano como dominante em sua obra, esteja ele diante dos olhos do sujeito ou em memória. Reconhecemos também a obra daqueles a quem Knopfli é comumente contraposto como sendo válida e necessária, às vezes como o próprio Knopfli o faz, às vezes utilizando elementos que Knopfli nos dá para a leitura de sua própria obra e aplicando-os na leitura desses outros poetas, e às vezes adotando também o ponto de vista desses outros poetas. Dessa forma, a defesa que aqui empreendemos da obra Knopfliana é sempre em relação a, e nunca em oposição à obra alheia. Achamos que Knopfli tem a mesma importância para a poesia em Moçambique que tem José Craveirinha. Mas por não ter assumido os mesmos compromissos pessoais, foi deixado de lado. Essa é a revisão que propomos na leitura de sua obra.

Agora, diante disso, iniciaremos uma análise de dois aspectos que julgamos fundamentais para a compreensão da obra do knopfli: a relação com o espaço e a poesia 
sobre a poesia. Afinal, como vimos destacando, esses elementos são essenciais na constituição do poeta e permeiam a sua obra de forma intensa, não podendo, é claro, ser tomadas como categorias estanques, como se pudéssemos extrair de sua obra apenas esses elementos, tendo em vista que há, quase sempre, uma ligação simbiótica entre cada componente da escrita de knopfliana.

Esses dois elementos têm tamanha importância porque sustentam a intenção do poeta em ser sincero consigo mesmo. Assim, acreditamos que uma releitura de toda a sua obra que leve em conta esses fatores podem reabilitar a poesia de Knopfli em Moçambique, mesmo a sua produção nos tempos revolucionários, e ainda apontar para uma revisão do cânone que possa incluir produções que têm como componente principal a subjetividade. Assim, ao assumir o compromisso com a fidelidade aos seus versos e à sua experiência, os versos de Knopfli vêm carregados de subjetividade, a mesma subjetividade que sustenta seus versos do início ao fim de sua escrita.

Após a consideração desses elementos, talvez seja possível observar as próximas gerações de poetas sob outra perspectiva. Obviamente, nós também partimos para uma análise do ponto de vista ocidental quando empreendemos essa análise. Não fosse depararmo-nos com textos que nos ajudassem a entender que a coletividade, por exemplo, era um componente cultural moçambicano, muitos dos elementos literários que se produziam época passariam despercebidos e ficaria ainda mais difícil não só apreender a obra de Knopfli como também de analisá-la de maneira contundente. Ainda nos fica um receio de que algum outro componente cultural se nos tenha escapado por deficiência desta pesquisa que ora empreendemos ou por falta de experiência e vivência em território moçambicano. De qualquer maneira, partilhando, portanto, do ponto de vista literário adotado por Knopfli, enxergamos em sua obra uma aproximação dessa cultura africana à europeia tão arraigada em sua obra. Veremos como isso se dá de forma mais aprofundada na análise desses dois aspectos já enunciados. 


\section{PAÍS E A PÁTRIA - O SUJEITO FORA DE LUGAR}

Knopfli nunca deixou de se afirmar africano, porém não reclama pra si a luta de sob a bandeira de uma nação. Às vezes, sua obra alcança justamente essa amálgama entre ser africano e não estar a serviço de um Estado específico, outras vezes, essa amálgama parece não se realizar por completo. No entanto, a dimensão literária, ou seja, o seu trabalho com a linguagem nunca é esquecido em favor dessa ou daquela afirmação. E essa luta para pertencer ao continente e tentar manter distância da luta nacional pela independência e pela construção de uma identidade nacional é potencializada pela crítica de sua obra. Muitas vezes guiada apenas ideologicamente. Nos versos do poema "Naturalidade", de seu primeiro livro com o título incrivelmente significativo de $O$ País dos Outros, podemos começar o estudo da obra Knofpliana propriamente dita, tendo em vista que nele o poeta sintetiza muito do que pretendemos desenvolver neste estudo.

\section{NATURALIDADE}

Europeu, me dizem.

Eivam-me de literatura e doutrina

europeias

e europeu me chamam.

Não sei se o que escrevo tem a raiz de algum

pensamento europeu.

É provável... Não. É certo, mas africano sou.

Pulsa-me o coração ao ritmo dolente

desta luz e deste quebranto.

Trago no sangue uma amplidão

de coordenadas geográficas e mar Índico.

Rosas não me dizem nada, 


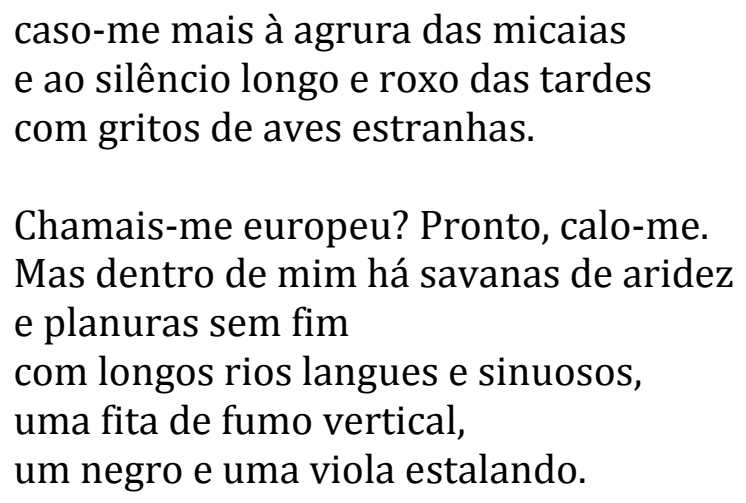

Este talvez seja o poema central pra tudo o que vimos falando a respeito de Knopfli. No início já se enuncia uma defesa, dizendo que ele é chamado de europeu. Essa identificação com a Europa não é negada. Afinal, é de sua ascendência e também de sua vivência que essa raiz de pensamento europeu permeia sua obra. No entanto, acima disso, Knopfli se diz africano. E argumenta a seu favor. Com o verso "Rosas não me dizem nada", ele tenta apagar uma das maiores imagens da poesia com a qual se identifica a produção poética da Europa, isto é, a rosa, nesse caso, é representante de uma cosmovisão contrastada às micaias, que têm como referente o espaço africano.

A princípio, o fato de calar-se quanto ao lugar que lhe é atribuído é uma atitude política. 0 poeta não nega que traz consigo algo de europeu, inclusive o assume, como o fará outras vezes em poemas como "Contrição". Mas afirma-se africano a despeito disso, apesar desses elementos culturais que traz em suas leituras e estão inseridos na sua produção promovendo uma intertextualidade marcante. Assim, sua resposta quanto a sua pertença a determinado espaço vem através dos versos que seguem, mostrando as imagens mais características de África compondo a subjetividade do sujeito poético. Mas pra quem essas imagens são características e representativas do continente africano? Para um observador externo? Para um ocidental? É essa a maior contradição de sua obra. Por vezes ele invoca a imagem de África de forma tão próxima de si que não podemos negar-lhe o estatuto de africano, em outras, no entanto, essa generalização põe em dúvida o seu lugar de enunciação, isto é, levantam a hipótese de ser mais um escritor a cantar o que África tem de exótico aos olhos ocidentais. Mas veremos que a representação do espaço em sua obra busca primeiro o objetivo de se afirmar, e depois, com o desencanto do exílio, torna-se um espaço de memória. Ao longo de sua obra, esse espaço africano não será mais que uma lembrança evocada e sua pátria não será mais que seus versos, mais que sua língua. 
0 ato de Knopfi dizer-se africano e não moçambicano implica uma resistência. Afirmando-se dessa forma, Knopfli não permite que os ideais nacionalistas de nenhum tipo permeiem seus versos. Trata-se de uma forma de manter-se afastado das disputas ideológicas e tentar ficar o mais próximo possível daquilo que ele admira no continente africano. Dessa maneira, Knopflli salvaguarda seus versos daquilo que, pra ele, não tem relação com a sua poesia, daquilo que não envolve, enfim, sua própria experiência.

Podemos, portanto, identificar com nitidez em seus poemas essa identificação com África. Contudo, não há uma identificação com a busca da identidade nacional promovida pelos outros expoentes da literatura e da intelectualidade moçambicana. 0 sentimento de pertença ao país Moçambique, às tradições ou, ainda, a identificação com a luta dos negros não lhe pode alcançar em sua produção poética. Ele escolhe não falar de vivências que não lhe são próprias. Knopfli sustenta o argumento de que as questões nacionalistas e raciais não podem tocá-lo como o fazem aos outros. Nas palavras do próprio Knopfli:

[...] sou duplamente estranho: estranho porque me reconheço como estranho, já tenho consciência das condições que me vão tornar estranho na própria terra, porque, mesmo que eu permaneça em Moçambique, serei sempre estrangeiro e branco. E os outros [os companheiros de café e poesia] escolheram os outros caminhos. 0 grupo... quer dizer: essa célula é destruída como um cancro, é pulverizada, não é? Até vem uma referência ao Rui Guerra. Escolheram outros caminhos. Nenhum deles regressou, já reparou? [...] é realmente a minha terra - mas uma terra em que sou estranho: como se tivesse nascido, acidentalmente, no Cairo, em Paris com a diferença que o nascer acidentalmente numa terra não nos faz dessa terra. Agora, o ter nascido numa terra que foi sempre a nossa terra e vir a descobrir que esta é que é a minha terra e nunca mais a poderei trair... Mas esta terra - de certo modo ingratamente - rejeita-me. Eu não sei, mas é uma coisa muito complexa. É e não é. (LABAN, 1998. p. 502)

Ele se diz estrangeiro e branco mesmo tendo nascido em Inhambane, no sul de Moçambique. Atribui esse estrangeirismo à terra que o renega, que o rejeita por aspectos alheios à sua vontade. E completa:

A verdade é que eu nunca poderia sentir como um europeu. Porque eu era só filho de europeus. A Europa para mim era só uma ideia, uma miragem, e todas as minhas vivências, aquelas que me tocavam mais de perto o coração, a não ser as culturais, eram todas de origem africana. [...] 
$\mathrm{Eu}$ nunca reivindiquei a nacionalidade moçambicana, só reivindiquei um facto, que ainda hoje reivindico, de ser africano. (CHABAL, 1994, p. 200)

Assim, ao ligar-se culturalmente ao espaço europeu Knopfli se põe numa posição um tanto quanto complicada. Afinal, de que perspectiva ele poetiza? Tendo em vista que sua obra caracteriza-se pela intertextualidade com muitos autores do espaço europeu, ele estaria apenas promovendo uma continuação dessa literatura? Como contrapeso, mais uma vez, invoco a honestidade que vimos, por exemplo, na sua arte poética. Sendo honesto e só deixando adentrar a sua poesia o que tem tripas, o que lhe é visceral e que faz parte de sua vivência, é impossível que esses espaços, europeu e africano, não se interpenetrem.

Dessa forma, Knopfli se vale dos aspectos formais no que tange às suas vivências culturais europeias, mas tem como núcleo sua experiência em África, suas vivências. Mais uma vez, como evocamos também na parte deste trabalho dedicada à sua arte poética, o poeta promove uma ligação simbiótica entre estes aspectos culturais e experienciais os vivenciados por ele.

Fica, portanto, difícil situar sua obra. Ela não se alinha aos discursos poéticos vigentes à época, no entanto também não reproduzia simplesmente um discurso exógeno. Não propagava uma poesia que já era feita em outros espaços. Ele sintetizava bem essa tensão em algo sem lugar ainda na poesia moçambicana. E por esse não lugar, sua obra acabou sendo renegada por uns tantos e defendida por outros, mesmo que por vezes apontassem Knopfli como mero continuador da poesia europeia metropolitana.

\subsection{No meio do caminho: o poeta entre espaços culturais}

O continente africano marca forte presença na poesia de Knopfli. A valorização deste continente através das técnicas da tradição literária ocidental é realizada de forma bastante consciente e, por vezes, desafiadora da própria tradição, trazendo suas referências para África, diluindo-as, aproximando-as de outro espaço, mas efetuando 
também o movimento inverso (aproximando o espaço africano às referências culturais que lhe são externas). Assim, Knopfli poetiza a relação entre sujeito de escrita e espaço proveniente do colonizador e não entre sujeito de escrita e espaço colonizado como fazem muitos de seus conterrâneos contemporâneos (MONTEIRO, 2003). Essa identificação e aproximação às referências do colonizador marcam sempre uma diferença em favor do espaço africano, que é sempre defendido pelo poeta. Vejamos um exemplo onde Knopfli consegue sintetizar seu sentimento de pertença ao território africano e suas origens, suas "raízes" europeias, de onde o poetas nos conta que provêm as suas referências culturais, naquele já citado jogo em que os espaços se interpenetram:

HIDROGRAFIA.

São belos os nomes dos rios na velha Europa.

Sena, Danúbio, Reno são palavras cheias de suaves inflexões, lembrando em tardes de oiro fino, frutos e folhas caindo, a tristeza outoniça dos chorões.

O Guadalquivir carrega em si espadas de rendilhada prata, como o Genil ao sol-poente, o sangue de Federico.

E quantas histórias de terror contam as escuras águas do Reno?

Quantas sagas de epopeia não arrasta consigo a corrente do Dniepre.

Quantos sonhos destroçados navegam com detritos à superfície do Sena?

Belos como os rios são os nomes dos rios na velha Europa.

Desvendada, sua beleza flui sem mistérios.

Todo o mistério reside nos rios da minha terra.

Toda a beleza secreta e virgem que resta está nos rios da minha terra.

Toda a poesia oculta é a dos rios da minha terra.

Os que, cansados, sabem todas as histórias do Sena e do Guadalquivir, do Reno e do Volga 
ignoram a poesia corográfica

dos rios da minha terra.

Vinde acordar

as grossas veias da água grande !

Vinde aprender

os nomes de Uanéteze, Mazimechopes,

Massintonto e Sábiè.

Vinde escutar a música latejante

das ignoradas veias que mergulham

no vasto, coleante corpo do Incomáti,

o nome melodioso dos rios

da minha terra,

a estranha beleza das suas histórias

e da suas gentes altivas sofrendo

e lutando nas margens do pão e da fome.

Vinde ouvir,

entender o ritmo gigante do Zambeze,

colosso sonolento da planura,

traiçoeiro no bote como o jacaré,

acordando da profundeza epidérmica do sono

para galgar os matos

como cem mil búfalos estrondeantes

de verde espuma demoníaca

espalhando o imenso rosto líquido da morte.

Vede as margens barrentas, carnudas

do Púngoè, a tristeza doce do Umbelúzi,

à hora de anoitecer. Ouvi então o Lúrio,

cujo nome evoca o lírio europeu,

e que é lírico em seu manso murmúrio.

Ou o Rovuma acordando exóticas

lembranças de velhos, coloniais

navios de roda revolvendo águas pardacentas,

rolando memórias islâmicas de tráfico e escravatura.

Ah, ouvidos e olhos cansados de desolação

e de europas sem mistério,

provai a incógnita saborosa

deste fruto verde,

destes espaços frondosos ou abertos,

destes rios diferentes de nomes diferentes,

rios antigos de África nova,

correndo em seu ventre ubérrimo

e luxuriante.

Rios, seiva, sangue ebuliente,

veias, artérias vivificadas

dessa virgem morena e impaciente,

minha terra, nossa Mãe! 
Com esse poema, Knopfli revela todo um espaço ainda por descobrir em solo africano. Mostra conhecimento sobre os espaços metropolitanos europeus e convida a (re)descobrir ou a (re)escrever as estórias desses rios, que podemos tomar metonimicamente como todo o continente africano.

Ooutro fator extremamente importante é o interlocutor deste poema. Afinal, a quem ele se dirige? Quem o poeta convida para conhecer os rios de sua terra? Ora, quem poderia ser senão aqueles que só conhecem os rios da Europa? Isso inclui tanto europeus quanto qualquer ocidental que tenha estudado a História da Europa. Esse dado é muito importante, pois vincula duas tradições, duas culturas em um mesmo poema, e é essa justamente a sua posição. 0 seu local de enunciação é quase sempre levado por essa perspectiva. Digo quase sempre pois nem sempre seus poemas conseguem sintetizar dessa forma essa aparente contradição, mas que na verdade não passa de uma tentativa de juntar essas tradições em versos.

Sobre esses aspectos Francisco Noa (1997), enquadrando Knopfli na modernidade da literatura moçambicana, diz:

A poesia de Knopfli, no que ela apresenta de conflitual, ambíguo, inovador, contraditório, aglutinador, sedicioso, autocrítico e antecipatório, assume-se inequivocamente como metáfora da modernidade literária em Moçambique. [...] Nas suas múltiplas e diversificadas vertentes, Knopfli terá africanizado essa modernidade [europeia], subvertendo-a, dilatando-a, reequacionando-a em função de especificidades temáticas e estruturais da sua escrita. 0 alargamento conceptual e espacial da modernidade revela que, no fundo, é ela própria uma busca de sentido. (p. 118)

Não contente com isso, ao final, o poeta elucida um sujeito singular ("minha terra") e um coletivo ("nossa mãe"), o que pode inseri-lo tanto como fruto de uma mãe africana, um filho de África, como também permite uma leitura mais abrangente. Levando em conta a quem se dirige o poema (aos metropolitanos europeus), busca uma identificação de pertença comum, ou seja, a África como mãe também desses sujeitos do espaço colonizador, promovendo mais ainda a união das culturas, sugerindo a mesma origem.

A identificação com o continente africano vem estampada nas referências a "batalhas", "morte", "detritos", "terror", "sonhos destroçados" associados aos rios 
europeus em oposição à "beleza secreta e virgem", ao "fruto verde", ao "ventre", à "seiva", ao "sangue ebuliente", às "artérias vivificadas", que seriam características dos rios africanos, repletos, portanto, de vida. Nos momentos em que imagens de teor negativo aparecem associadas aos rios africanos, elas apenas salientam, por oposição, a resistência e a vida ali presente, como o rio gigante que acorda para "galgar os matos/ como cem mil búfalos estrondeantes/ de verde espuma demoníaca/ espalhando o imenso rosto líquido da morte".

Em "Navio no Porto", o sujeito poético assume um estranhamento com relação àqueles que vêm de fora e chegam ao seu território. 0 navio panamense, representando o outro, causa estranhamento através de sua tripulação por suas diferenças culturais e linguísticas e por suas feições.

\section{NAVIO NO PORTO}

Vamos até ao cais ver o navio panamense.

Com as suas cores sujas, a tripulação descalça e bronzeada, de feições índias e mulatas - tem um aspecto estranho o navio panamense.

Na franja doirada de sol paira o gárrulo das camisas e, sobre a brisa molenga, flutuam fonemas espanhóis.

A gente vê cá em baixo o negro, mais negro do carvão, cirandando debruçado e, lá em cima, a cor e a música das vozes em torno dum transistor pequeno. A gente vê uns e vê os outros, vê mares abrindo-se e cais fechando-se.

E a gente pensa, olhando com olhos estranhos a estranheza do navio panamense.

Em três versos deste poema, podemos ver claramente a posição do sujeito em relação ao que acontece com a chegada do navio panamense: "A gente vê uns e vê os outros,/ vê mares abrindo-se/ e cais fechando-se”. A distância com relação ao outro é 
marcada não só pelo fechamento do cais, mas também pelo artigo "os" que antecede a palavra "outros". Fica claro como o cais, fechando-se, marca a distância entre quem recebe o navio e quem nele chega, que, por sua vez, vê mares abertos. Outra marca do distanciamento do sujeito com relação aos que chegam é o isolamento da palavra "panamense", por duas vezes durante o poema e, na terceira vez em que ocorre um verso com uma única palavra, o termo escolhido é "estranhos".

Nos três versos finais, no entanto, a situação fica mais complexa: o navio é estranho àquele que já traz o olhar estranho. Esse poema resume de forma incrível a lucidez que tinha Knopfli de sua condição, e ainda nos mostra a complexidade de seu lugar de enunciação.

\subsection{A pátria da língua}

O segundo poema de $O$ escriba acocorado, talvez o mais emblemático por conta de um de seus versos, chama-se "Pátria". O título é por si muito expressivo pela relação conturbada que Knopfli mantém com a temática. Este poema pode nos propiciar um melhor entendimento da relação de Knopfli com a questão nacionalista.

II. Pátria

Um caminho de areia solta conduzindo a parte nenhuma. As árvores chamavam-se casuarina, eucalipto, chanfuta. Plácidos os rios também tinham nomes por que era costume designá-los. Tal como as aves que sobrevoavam rente o matagal

e a floresta rumo ao azul ou ao verde mais denso e misterioso, habitado por deuses e duendes de uma mitologia que não vem nos tomos e tratados que a tais coisas é costume consagrar-se. Depois, com valados, elevações e planuras, e mais rios

entrecortando a savana, e árvores e caminhos, aldeias, vilas e cidades com homens dentro, a paisagem estendia-se a perder de vista 
até ao capricho de uma linha imaginária. A isso

chamávamos pátria. [...]

Neste trecho do poema o sujeito define sua primeira pátria, cujas referências ao mundo da infância abundam. 0 caminho de areia solta que conduzia a parte nenhuma era justamente onde se queria estar, "parte nenhuma" não era delimitada. As palavras apenas nomeavam as coisas que "parte nenhuma" continha, coisas que era de costume nomear, no entanto, havia toda uma mitologia que os tomos e tratados não poderiam conter. Não era do domínio da história, senão da experiência do próprio poeta. A paisagem era infinita, tendo em vista que se perdia de vista, somente limitada por uma linha imaginária, portanto, distante do alcance da percepção. Era uma pátria onde o limite era apenas o da imaginação, onde os limites impostos pelos homens não tinham valia.

\section{[...]Por vezes, de algum recesso}

obscuro, erguia-se um canto bárbaro e dolente, o cristal súbito de uma gargalhada, um soluço indizível, a lasciva surdina de corpos enlaçados. Ou tambores de paz simulando guerra. Esta não se terá feito anunciar por tal forma

remota e convencional. Mas o sangue adubou a terra, estremeceu o coração das árvores e, meus irmãos, meus inimigos morriam. Uma só e várias línguas eram faladas e a isso, por estranho que pareça, também chamávamos pátria. $[\ldots]$

No segundo momento do poema, há o contato com a vida mais real, os sentidos são usados para perceber as ações que estão ocorrendo à sua volta, desenvolvendo principalmente a ideia de acontecimentos corriqueiros transcorrendo ao longo dos dias. No entanto, há uma alusão à guerra. A princípio, os tambores apenas imitavam a guerra, fazendo parte também do cotidiano, mas a guerra veio efetivamente e perturbou tudo aquilo que antes era a pátria do sujeito: o sangue na terra abalou até o coração das árvores. Nomeando também essa terra repleta de horror e sangue como pátria, o poeta se revela também afetado por aquilo que acontece à sua volta.

A questão da língua se mostra bastante significativa ao final deste trecho. A divisão entre "uma só" e "várias línguas" marca a diferença no campo de batalha: de um 
lado os portugueses, de outro os africanos que tinham consigo muitas diferenças étnicas e, consequentemente, linguísticas. E a esse aglomerado de línguas características de cada etnia, de cada lado da batalha, caracterizou, em algum momento, outra pátria.

\section{$[\ldots]$}

De quatro paredes restaram as paredes. Com as folhas de zinco e a madeira ferida dos travejamentos perfaziam uma casa. Partes de um corpo desmembrado, dispersas ao acaso, vento e silêncio as atravessam e nelas não dura a memória

que em mim, residual, subsiste. Sobre escombros deveria, talvez, chorar pátria e infância, os mortos que lhe precederam a morte, o primeiro e o derradeiro amor. Quatro paredes tombadas ao acaso e isso bastou para que, no que era só mundo, todo o mundo entrasse

e o polígono demarcado, conservando embora a original configuração, fosse percorrido por um arrepio estrangeiro, uma premonição de gelos e inverno. Algo lhe alterara imperceptivelmente o perfil, minado por secreta, pertinaz enfermidade.

Semelhante a qualquer outro, o lugar volvia meta e ponto de partida, conceitos que, como a linha imaginária, circunscrevem, mas de todo eludem, o essencial, Ladeado de sombras e árvores, o caminho de areia, que se dizia conduzir a parte alguma, abria

para o mundo. A experiência reduz, porém, a segunda à primeira das asserções: pelo mundo se alcança parte nenhuma; se restringe ficção e paisagem ao exíguo mas essencial: legado de palavras, pátria é só a língua em que me digo.

Depois da guerra, só restou a destruição por ela causada, todas as pátrias construídas pelos homens foram também por eles destruída. A imagem da destruição é bastante intensa. Somente restam escombros do tempo anterior, mas o poeta não tem a intenção de evocar o antigo escapismo romântico para o mundo da infância, embora a memória seja parte importante de sua obra. A imagem dos mortos que precedem a morte dos seus espaços privilegiados não o faz chorar nem pátria (a primeira) nem a infância que a construiu. 
Assim, as paredes tombadas, que podemos tomar como outro processo metonímico característico da poesia de Knopfli, abrem a pátria para o mundo, mas deixam também um arrepio estrangeiro adentrá-la, o que a transformou em outra coisa, em algo muito diferente do que já tinha sido um dia e essa transformação não é positiva.

As duas últimas estrofes são bem marcantes no que tange à experiência do sujeito. O lugar passa a ser semelhante a qualquer outro, perde sua qualidades diferenciais, na luta por construir uma pátria, de afirmar a diferença, tudo o que conseguiram, na visão do poeta, foi a semelhança. Os espaços conquistados não revelam a paisagem, a pátria, mas passam a esconder tudo aquilo que tinham de diferencial para deixar entrar o mundo.

Retomando o início do poema, há uma inversão dos valores após a vivência do sujeito, que através do mundo não pode mais encontrar aquela primeira "parte nenhuma" que na primeira estrofe se mostrava e descortinava o mundo do sujeito. Há, portanto, o apagamento daquela pátria primeira que era parte nenhuma, mas também o mundo todo, restando da paisagem e da ficção (da memória) só o essencial e as palavras, portanto, se só as palavras restam, a pátria do sujeito só pode se limitar a elas: “Legado/ de palavras, pátria é só a língua em que me digo".

Temos, portanto, um sujeito que traz a memória de si relacionada diretamente à terra. Sua experiência não lhe permite reconhecer um espaço total, nacional a não ser aqueles evocados pela lembrança, e estas, por sua vez, evocadas por palavras. Que lhe resta então senão uma pátria de palavras? A este respeito, Matusse (1998) diz:

Existe entre a língua e a cultura uma interacção que resulta numa influência mútua. [...] Ora, sendo o trabalho da cultura o de organizar estruturalmente o mundo que rodeia o homem, ela precisa de um "dispositivo estereotipizador" estrutural, que proporcione aos membros de uma dada comunidade o sentido intuitivo da estruturalidade, que transforme o mundo aberto dos realia no mundo fechado dos nomes, obrigando os homens a interpretarem como estruturas fenómenos cuja estruturalidade não é tão evidente. Esta função esteriotipizadora é desempenhada pela língua. (p. 40)

Daí a língua ser pátria de Knopfli, por organizar estruturalmente a sua pátria da memória. A pátria passa a ser não mais física ou ideológica, mas apenas linguagem. Isso se dá não apenas por escolha do próprio poeta, mas, pelo que vimos no poema "Pátria", 
pela destruição daquilo que antes representava a sua pátria, deixando pra trás o "exíguo mas essencial", um "legado de palavras".

Precisamos lembrar também de que o livro ao qual esses dois poemas pertencem, O escriba acocorado (1978), é o primeiro após sua saída de Moçambique. Portanto, esse livro é de fundamental importância para o rumo que sua obra vai tomar. Knopfli alega que deixou o país por motivos de "segurança". Ele muda-se para Londres logo após a independência, onde se tornará funcionário da embaixada portuguesa. Desse modo, a sua afirmação "Pátria é só a língua em que me digo", uma das mais fortes e marcantes de toda sua obra, decorre do fato de ele estar desterrado, não de África, afinal, o próprio poeta escolheu como destino a Europa, mas de Moçambique. Um Moçambique que, transformado pela independência, não poderia mais lhe dar abrigo.

Esta é mais uma das incontáveis disparidades que cercam a vida de Knopfli e sua obra. Como quando ele diz, em suas palavras, que a situação colonial não era criminosa, mas sim "anômala", parece comprometer toda a defesa que faz de sua pertença ao continente africano. No entanto, quando completa mais adiante que ele não pode falar de outra perspectiva que não a dele, o que não o redime em nenhum momento de qualquer outra afirmação, Knopfli está dizendo, em outras palavras, que ele não pode deixar de ser honesto, que se recusa a ser hipócrita e que essa honestidade é o que guia os seus versos. Essa é a toada de todos os seus depoimentos quanto à sua obra. Será, por isso, menos válida que qualquer outra concepção de poesia?

Em um comunicado à Associação dos Escritores Moçambicanos, em 1989, Knopfli discorre sobre a pátria e sobre a literatura nacional. Nesse comunicado, Knopfli mais uma vez usa a metáfora de Caliban e Próspero. Sob sua perspectiva, restava a Moçambique, depois de postos senhor e escravo em pé de igualdade:

[...] quando escravo e senhor se enfrentam, olhos nos olhos, no terreno em que não resta já mais lugar para escravos e senhores, senão para homens dialogando com homens na pátria de uma língua comum.

Inicialmente, mau grado todas as atenuantes, mas em seu prejuízo imediato, Moçambique não entendeu isso. Portugal, perdido nas suas mais que muitas quezílias internas, também não soube ou não pôde acompanha-lo devidamente. Presumo que é mais que tempo de se pôr cobro ao mal-entendido, no espaço generoso do aqui que principiei por apelidar de "denominador comum", aquilo 
que nos une para além e por cima da indispensável vontade política, por mais teimosa e persuasiva que esta o seja [a língua portuguesa]. (p. 19)

Dessa forma, Knopfli tenta se eximir de qualquer possível culpa por conta da colonização. Agindo dessa forma, ele apaga, ou omite, todas as atrocidades que a situação colonial proporcionou para Moçambique e seu povo. Não em benefício próprio, a princípio, mas por estar ele contido na minoria da população que, até a independência, era a beneficiada. Assim, o que o poeta chama de mal-entendido é uma tentativa de acerto de contas, como se fosse possível reparar 500 anos de exploração por parte dos portugueses.

Porém, disso tudo se salva o "denominador comum", isto é, o que pode ter sido a maior violência da colonização portuguesa e, ao mesmo tempo, algo que pode também unir povos sob uma bandeira única.

No começo de seu comunicado, Knopfli deixa bastante claro a alegria com a sua "volta" a Moçambique. Essa volta se deve ao convite da Associação para realizar esse comunicado, ou seja, estar novamente no rol dos escritores moçambicanos. E ainda, na sua volta, deixa claro o desconforto em escrever, em dizer "eu" em tempos em que isso era quase proibido. Assim, Knopfli, como dissemos, foi condenado por adiantar a modernidade da literatura Moçambicana, em que se difunde a individualidade. Dessa forma, condenou-se a literatura de Knopfli a um exílio e, com a independência, o próprio Knopfli preferiu exilar-se. Sobre essa constante vigilância Knopfli diz:

Como inevitável corolário, na senda do 25 de Abril, dos inevitáveis atropelos e na emergência dos novos países africanos de expressão veicular portuguesa, não tardariam a surgir - armados de régua e esquadro, de compasso ou fita métrica, ou instrumentos mais agressivos (chamboco?) - os polícias do espíritos-esbirros incapazes de dar-se conta de que reproduziam, apenas, a imagem invertida do sinistro sujeito que levava a mão à pistola sempre que ouvia falar de cultura. (p. 20)

Dessa forma, o poeta identifica a mesma atitude que tiveram os portugueses durante os anos de colonização, quando a vigilância, principalmente cultural, era extrema, com o período revolucionário, onde também se perseguia aqueles cujas ideias diferiam do movimento de libertação, contrários a eles ou apenas diferente. 
Na sequência, ele busca explicitar sua forma de encarar a nacionalidade literária:

A palavra de ordem, uma só: quem são os escritores africanos de Língua Portuguesa? Os que saíram ou os que ficaram, antes ou depois das independências? Os mais clarinhos ou os mais escuros? Isto, a despeito de Lobato ter sustentado por toda a parte e sempre que a oportunidade surgia, que em Portugal, depois do século XVII, ninguém poderia gabar-se de ser branco... Ainda assim, os "legisladores" haveriam de decretar e determinar, classificar a seu bel-prazer, em diatribes por vezes odientas, mas em vão: Noémia de Sousa está ausente de Moçambique o dobro dos anos que somam os do meu afastamento e ninguém questionaria o seu moçambicanismo, por certo mais representativo que o meu. (p. 20)

Assim, Knopfli questiona as bases do pensamento utilizado para definir a nacionalidade literária de um escritor, inclusive a sua própria. Essa atribuição da nacionalidade passa a ser dever de "legisladores". Claro está a ligação entre a política e a nacionalidade dos escritores aqui mencionada Basta lembrarmos de que é justamente nesse período que teremos a afirmação das diferenças em relação ao colonizador português, a tentativa de se criar uma identidade nacional consistente e que abranja toda a pluralidade cultural confinada num mesmo território para, então, unir um vários grupos étnico-culturais sob a mesma bandeira, lutando por uma mesma causa. Portanto, imperou o sujeito coletivo "nós", que buscava cativar no outro a vontade de partilhar aquele espaço ideológico que estava se forjando, buscava-se definir no imaginário de todos o significado da palavra "Pátria".

Ao evocar a lembrança de Noémia de Sousa, Knopfli busca uma semelhança, algo de comparável entre os dois. Nesse caso, temos o exílio, que se deu por razões diferentes. Noémia trabalhava em Lisboa, todavia, por conta de sua oposição ao estado, acaba exilada e vai trabalhar na embaixada do Marrocos. Knopfli, por sua vez, decide-se por deixar o país após a independência, no que ele próprio chama de "questão de segurança". Tendo em vista sua ascendência, Knopfli exilou-se com medo de uma represália cega que o viesse a procurar apenas pela cor da sua pele ou pelo fato de ele não defender, em sua obra, os mesmo ideais dos revolucionários. Independentemente dessas razões, Knopfli ressalta que Noémia também se ausentou de Moçambique. Não podendo, portanto, ser esse um critério de pertença de um e exclusão de outro quanto à nacionalidade moçambicana. 
A "Pátria" implica não apenas um espaço físico, geográfico, mas também o sentimento nacionalista, de ligação afetiva com aquele espaço. Mas também implicou os aspectos ideológicos e, justamente nesse ponto, Knopfli era diferente. Enunciava-se sempre em primeira pessoa, antecipando, como já dissemos, a modernidade da literatura moçambicana (MATUSSE, 1997). Por motivos que já elucidamos, o poeta acreditava nisso, acreditava que não poderia exprimir-se de outra maneira. Por conta das referências culturais que trazia dos grandes centros europeus e também angloamericanos, Knopfli escrevia a partir do espaço proveniente do colonizador, mas não em espaço colonizado, isto é, a sua produção se deu ocupando o espaço que lhe fora dado. Caso Knopfli tivesse feito juras de amor à pátria em seus versos, afirmasse a consolidação da nação, tratasse de tentar forjar uma identidade nacional, os legisladores o chamariam de moçambicano? Sua poesia seria mais facilmente alocada? Seus versos teriam a mesma validade que os de um Craveirinha? Se Knopfli tivesse permanecido em território moçambicano a crítica poderia ter amenizado os ataques à sua obra? Estas, entre outras, são perguntas para as quais não teremos jamais uma resposta. Sabemos, sim, que houve, anos após a revolução, a tentativa de repatriar os versos de Knopfli. Tomando por base aquele pensamento de que seus versos antecipam a modernidade da literatura moçambicana, quando ela, a modernidade, se difunde, tenta-se trazer de volta a poesia de Knopfli. Ou seja, quando o contexto político-econômico se mostra favorável, resta guardar na memória, relegar aos feitos do passado e estudar apenas como uma espécie de literatura de formação, no sentido de que ela estava em busca de afirmar-se, toda a literatura produzida durante o período revolucionário. Assim, apaga-se a produção que afirmava uma subjetividade em meio à coletividade revolucionária. Houve, ao fim e ao cabo, um sequestro da obra de Knopfli no cenário da literatura moçambicana.

A subjetividade complexa presente na obra de Knopfli procura o tempo inteiro aproximar as referências que traz. Knopfli diz que as suas referências são todas africanas, a não ser as culturais. A melhor tradução que encontramos para essas palavras é a de que o poeta não consegue dizer as suas experiências, não consegue transformá-las em poema senão através de um processo advindo do seu espaço cultural. Isso só faz aproximar ainda mais esses dois mundos. Mas um fator ainda mais complexo é o fato de, por exemplo, os poetas que produziam na mesma época cuja temática era mais engajada ideologicamente também se valerem de uma língua proveniente do 
espaço dominante. A estratégia utilizada por Knopfli não difere muito da utilizada por estes outros poetas. Eles subverteram a língua à sua vontade, aproximaram a língua escrita portuguesa ao máximo da oralidade, inseriram termos de línguas nativas. Knopfli, por sua vez, subverteu as imagens da poesia desses espaços dominantes. Como se dissesse nome de outro país em português, ou seja, dobrou à sua vontade o referente cultural para dizer o que melhor lhe representava, ou seja, a pertença à África.

Um exemplo claro do que estamos aqui argumentando pode ser lido no poema que segue:

\section{O CAMPO}

Saio para o campo. 0 campo

aqui não é o campo, mas a savana

eriçada de macaias e capim

feio e desigual. Habitantes

do seu mundo, os negros ignoram-me,

empenhados em suas tarefas quotidianas.

Olho para as coisas abandonadas,

latas escuras de ferrugem, lonas pardas de pneu, ferros

retorcidos sem jeito. Entre isso

o capim espreita, descolorido, espigado

e hirsuto. Nada me sugere a face

aveludada de uma paisagem pastoril,

rosto tranquilo de criança sonhando.

Mas eles estão no seu mundo,

e eu passeio no campo.

O que Knopfli chama aqui de "campo" é, na verdade, a savana. A paisagem que ele tem em mente não é "campo" pastoril cantado por outros poetas, seus referentes literários, mas a savana. 0 poeta cruza os dois mundos, traz o "campo" à savana e também marca na savana o sentimento que ele tem. Knopfli diz não poder sentir senão como um europeu. Quando diz isso, tem em mente justamente o referente cultural europeu e anglo-americano, que foi a fonte das leituras que o formaram. Mas ele também estava marcado pela experiência de viver em território africano. Assim, aproxima os dois mundos, quase como o fez com as rosas e micaias em outro momento, mas dessa vez não há oposição. 0 que há é uma interpenetração desses espaços, cultural e físico, gerando um local de enunciação complicado e que tem em seu centro o poeta.

Knopfli marca ainda uma diferença de mundos, o dos negros que o ignoram e o seu. $\mathrm{O}$ mundo do poeta é intermediário. Não pode ser europeu pois todas a sua vivência 
se deu em meio àquela terra. Portanto, o campo não pode jamais ser o campo europeu. Porém, ele também não pode aspirar a savana dos negros que o ignoram, pois não saberia como dizê-la. Fazendo isso, o poeta nos diz que a savana está pra ele como o campo está para os poetas europeus.

Com tudo isso o poeta corrobora quando diz:

Pessoalmente devo confessar que nunca terei escrito um verso, ainda quando roubo a Camões, ou colho em Shakespeare, em que Moçambique não esteja presente. Se digo Tamisa, ou escrevo Aron, penso Incomati ou Limpopo, rios que emolduram e glorificam a minha infância, a minha formação, inicial e definitiva, desde uma Moamba longínqua onde meu pai sedimentaria uma amizade, sempre reafirmada e nunca traída, com o excepcional patriarca Raul Honwana, ambos, a seu diferente ou oposto modo, funcionários da administração colonial. A partir de qualquer fonte determinante e original, da Moamba, por exemplo - e porque não? -, o criador é sempre o resultado da sua inteligência, sensibilidade e cultura, irremediavelmente agravadas pelo seu circunstancialismo, e tanto pode produzir um Luís Bernardo como... um Rui Knopfli, até porque nem no lugar e na época os circunstancialismos coincidiam. Por mim não pude escapar ao meu, como se verifica pelo juízo da crítica portuguesa que, mesmo quando me estima e acarinha, não sabe onde inserir-me ou arquivar, e a moçambicana, hesitando perplexa entre a pura rejeição e a parcial, quase envergonhada ou marginal aceitação.

Por tal motivo me espanta que se ressuscite, ainda hoje, a querela gratuita da nacionalidade literária que, de facto, não existe. $\mathrm{Na}$ verdade aquela é uma evidência e não um decreto, não surge de imposições externas, mas das coordenadas especiais que nos conjuraram ao discurso criador no espaço que nos foi consignado. (p. 20)

Neste trecho de sua comunicação, Knopfli busca outra comparação. Agora, isso se dá com o escritor Luis Bernardo Honwana. O contexto no qual estava o poeta inserido não o impedia de viver as coisas de África. Assim como não impediam Luis Bernardo. A diferença está nos aspectos que levaram Knopfli a levar mais em conta sua subjetividade, isto é, seu contato com as culturas e literaturas que tinham como centro o sujeito mais que a comunidade, como é de praxe nas culturas ocidentais. Assim, o circunstancialismo ao qual Knopfli se refere é justamente esse contato com culturas diferentes durante a sua formação que o levaram para caminhos diferentes, e fica ainda a dúvida do próprio poeta se seriam "opostos", ainda que partilhassem um território e 
uma época. No mesmo período de tempo e compartilhando o mesmo espaço geográfico, Knopfli e Honwana vivenciaram experiências diferentes, sejam elas culturais ou não, que deixaram "cicatrizes" que os fizeram imprimir "tripas" aos seus escritos. Passadas, por tanto, pelo filtro da experiência, suas obras não poderiam ser senão diferentes.

Mesmo em um contexto em que a subjetividade toma conta desses espaços de enunciação em poesia, Knopfli também tem dificuldade para se enquadrar. Parar provar esse argumento, o poeta utiliza a crítica literária portuguesa, que também não encontra, senão às margens, um local onde inserir a literatura produzida por ele. Nos espaços de onde julgava-se vir o discurso de Knopfli, ele também não poderia ser completamente aceito. Esses problemas eram tanto de ordem nacionalista, isto é, Knopfli é moçambicano, portanto não podia ser aceito totalmente por Portugal, como orbitavam o aspecto ideológico, sabendo que Knopfli desde seu primeiro livro afirmava-se africano. A solução encontrada pelo poeta para resolver esse sobre nacionalismo foi o de assumir como fato de que nasceu em Moçambique e sua literatura não poderia, portanto, pertencer a outro lugar, a despeito de sua qualidade ou conteúdo. Assim também o faz quando cita a literatura de colonos produzida em território moçambicano. Cita exemplos de colonos que denunciavam os abusos de colonizadores e também de colonos que escreviam buscando animalizar os "nativos". A ambos ele confere o mesmo estatuto. Ambos pertencem à História de Moçambique e é preciso lê-los para saber de onde vêm os moçambicanos e, conhecendo o seu passado, decidir pra onde vão. Criando portanto uma tradição com a produção literária e histórica que se deu ali.

Diante dessas afirmações de Knopfli, subjaz um sentimento de pertença àquele país. Mas um sentimento que se despe de correntes ideológicas, como desvelou a rosa durante a sua obra. Assim, aquele espaço toma conta de seus versos não como pátria, não como nação, mas como espaço. Ainda, ao falar em "denominador comum", Knopfli reafirma a sua pertença a uma tradição maior que a moçambicana, mas também não isento dela. Defendendo a língua como Pátria, ele escapa às querelas que só o conduziriam a um discurso que lhe seria externo, tendo sido o poeta também forjado pelos elementos que já citamos.

Tendo em vista estes aspectos, podemos entender melhor a visão do próprio poeta quanto ao seu espaço, quanto a sua "classificação". É possível vislumbrar a ideia que Knopfli fazia de seu lugar de enunciação. Assim, negando em seus versos o 
nacionalismo, ele não nega sua nacionalidade. Entrega-se a algo que, em sua visão, excede, extrapola esse conceito. Dizer-se africano é uma forma de resistir à essa ideologia que tomava conta de Moçambique, mas, ao mesmo tempo, mostrar a sua ligação com aquela terra.

\subsection{A dor de lembrar}

Em $O$ corpo de Athena, publicado em 1984, os poemas que tem como temática o espaço africano, seja Moçambique ou África como um todo, adquirem um tom muito mais triste, marcado pelo saudosismo e por uma lembrança dolorosa. No ano de sua publicação, Knopfli já somava nove anos de afastamento de sua terra.

Nesse mesmo livro, depois de uma primeira seção de poemas sobre a própria poesia, Knopfli dá início a uma seção em que vai buscar o referente espacial, isto é, uma seção de poemas cuja temática principal é a relação do sujeito com o espaço. 0 espaço que não está mais ao alcance da visão do sujeito, mas somente em memória é avistado. A saga do viajante que retorna à sua terra, como Ulisses, já não é possível, tendo em vista que o retorno é também um exílio para o poeta. Voltar ao seu cais original, ou seja, o cais português, reduto de sua ascendência, não constitui uma volta pra casa. Knopfli já havia escolhido como pátria a língua portuguesa, mas ainda em África repousava a sua fidelidade. Assim, mais uma vez retomando essa fidelidade, a paisagem que opera nos versos após o seu exílio não poderia ser outra senão a de Moçambique.

O primeiro poema que evoca o que podemos identificar como um território africano é marcado por um tom dolorido de saudade e de algum ressentimento.

\section{DERROTA}

Mágoa índica, doída saudade ao sol-poente de praias na distância, travado na garganta o soluço à luz crepuscular que persiste e teima não tornar-se olvido. Sal saudade, padrão, dura lembrança erguida 


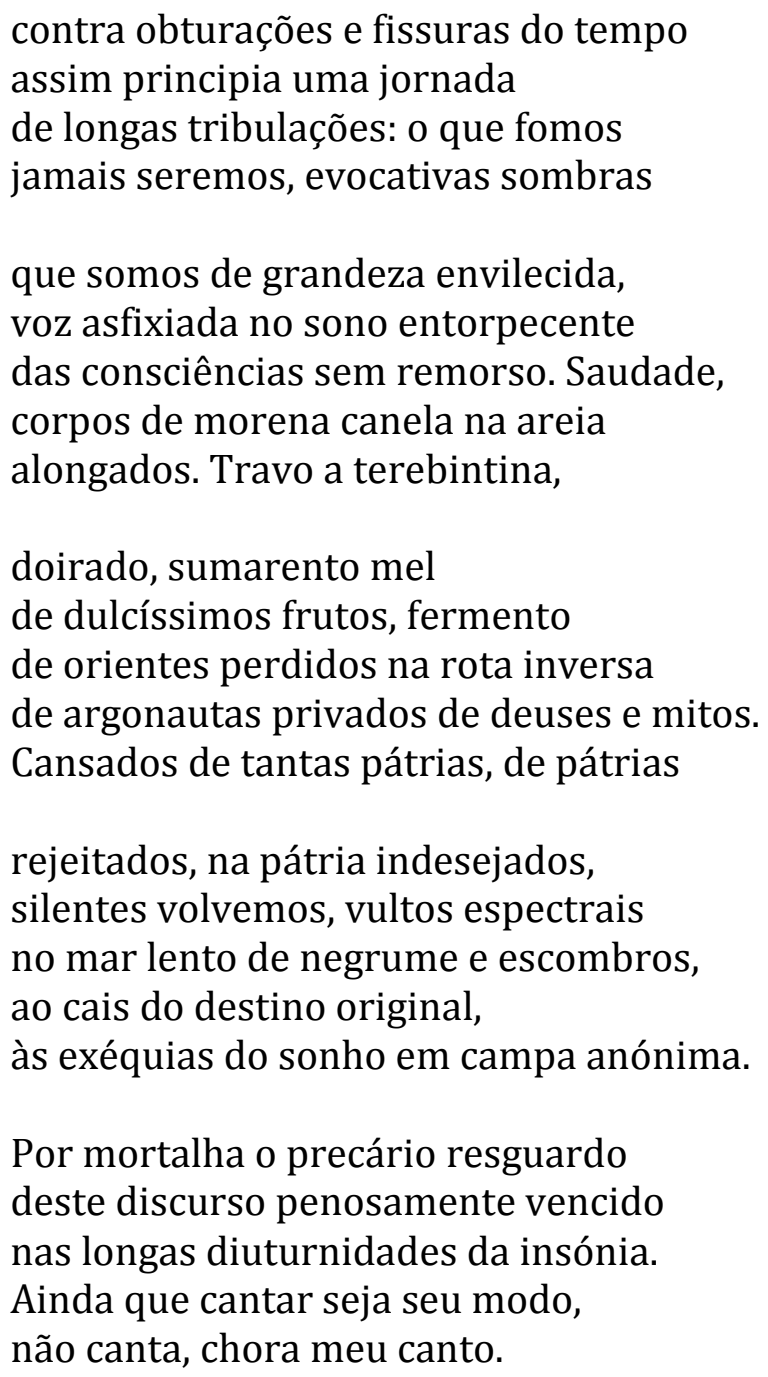

Vê-se nesses versos, a começar pelo próprio título do poema, o descontentamento do sujeito. A “derrota” estampada vem sob, pelo menos, duas formas: a da guerra que culminou na independência de várias colônias ultramarinas portuguesas, se tomarmos o aspecto histórico envolvido diretamente na produção de Knopfli, e também a derrota do sujeito que, com a independência, perde seu espaço e tem de regressar ao "cais original" por motivos alheios à sua vontade. Como já dissemos, Knopfli, após a revolução libertária em Moçambique, julgou não ser segura a sua permanência em território moçambicano, temendo uma represália cega tendo em vista a cor de sua pele e sua ascendência portuguesa. Dessa forma Knopfli escolhe abandonar Moçambique.

O discurso é vencido e conformado, ressentido da derrota. O retorno, desprovido de deuses ou mitos, destituindo, portanto, a bravura evocada pelo épico d'Os Lusíadas, revela uma tristeza onde a saudade tipicamente portuguesa impera. 0 
ressentimento maior, como não poderia deixar de ser, é com a pátria, onde fora rejeitado e indesejado, a pátria que o faz regressar ao "cais do destino original", a pátria que o derrotou. Afinal, com o advento da pátria Moçambique, Knopfli tem de empreender esse retorno. A palavra "pátria" assume, portanto, um significado muito maior que a mera delimitação de um espaço com o qual se tem ligação. A par do contexto em que Knopfli escreve, cria-se uma oposição excludente entre a pátria e o sujeito. Eles não podem dividir o mesmo espaço, um não pode existir no mesmo espaço que o outro. E esse é o grande ressentimento que dá o tom ao poema. Uma questão, porém, se impõe: sendo Knopfli nascido em Moçambique e tão assumidamente africano, de onde vem esse sentimento de retorno? Ele assume a tradição da qual faz parte e, ao voltar ao espaço em que ela impera, dilui-se, esvazia-se, deixando para trás apenas os versos, "o canto" que já não mais que um lamento.

A partir dessa "derrota", os versos passam a adotar um pessimismo mais denso, sempre com a ideia de desaparecimento do sujeito, cujos resquícios seriam apenas os versos, o memorial de uma existência que, derrotada, assume-se anônima e fragmentária. A obra é o que restaria do sujeito, mas não ele próprio.

Longe embora, como a bruma ou a luz por ela, no tempo

me excederá este avaro punhado de palavras, feitas não já o sonho sonhado, mas a liberdade a prumo em que outros possam, porventura, sonhar os limites do próprio sonho.

Dessa forma, o sujeito se apaga por trás da obra, ruma ao desaparecimento deixando como legado de si, apenas as palavras que não mais o representarão. Sua obra, por fim, não é sua, mas apenas limite do sonho alheio à altura em que é esquecido, em que se dilui.

Em seu último livro, essa tendência à dissolução do sujeito atenua-se, embora ainda bastante presente e perceptível. Assume o tom um saudosismo da infância, quando em terras africanas se encantava com a magia que o cercava. Mais que isso, o sujeito é um guardião de memórias. Ele escreve contra o esquecimento, mas certo de que será por ele engolido. Ou se perderá na memória que mais não é do que a própria obra. 
África invade tanto $O$ monhé das cobras como $O$ corpo de Athena. 0 espaço africano está o tempo todo na memória, sendo invocado para um presente triste e crepuscular, que é, ao fim e ao cabo, o tom de quase toda obra de Knopfli, mas aqui vem reforçado pelo isolamento do poeta que, exilado na metrópole inglesa de Londres, chega a dizer:

Cada homem é uma ilha cega na mais densa cerração (“Um rio votivo”, p. 476.)

Com todos esses elementos, a pátria e Moçambique não são mais que um espaço reservado na memória que ainda se recusa a assumir a pátria, a nação, motivo pelo qual teve de abandonar África. Ao trazer à tona a lembrança da infância, a pátria ou outros tipos de envolvimentos políticos não podem estar presentes, e quando estão, estão apenas para provar a sua ausência. Assim, Knopfli escapa dos seus antigos demônios e deixa-se ir diluindo à sombra de seus versos. Como o monhé das cobras que some ao longe após um dia de magia e encanto à beira da estrada e não volta mais. Ele permanece apenas na memória daqueles que o lembram em seus feitos, extraordinários aos olhos de uma criança. Ao fim, não há espaço maior que a memória de África para o poeta que, vencido pela pátria, retrai-se para dentro de seus versos, fragmenta-se neles, e vai depositando-se, sedimentando-se em cada palavra, seu legado: "legado de palavras, pátria é só a língua em que me digo". 


\subsection{Knopfli e Craveirinha - 0 país de quem, afinal?}

Falamos até agora da relação de Knopfli com o espaço africano e com a pátria Moçambique. Para que essa análise ganhe mais sentido, vamos aproximar esse aspecto de sua obra à poesia de José Craveirinha. Assim, poderemos ver claramente a importância de Knopfli não assumir essa pátria moçambicana.

Fátima Mendonça (2002), em um estudo sobre o conceito de nação em Craveirinha, Sérgio Vieira e Knopfli, assume claramente uma defesa da poesia de Craveirinha como constituidora de uma nação, como se a própria delimitação do território moçambicano fosse pela obra dele traçada. No mesmo artigo, a poesia de Knopfli é atacada, recortada e usada para contrapor-se à de Craveirinha. A autora chama Knopfli de pequeno burguês e o acusa de não tomar partido nos movimentos políticos do país. No entanto, não pressupõe que não dizer nada e ficar em silêncio, como pretende o poema "Naturalidade" são duas coisas diferentes.

De fato, o poeta não se assume moçambicano, não se alinha a nenhum pensamento político. Ele não assume pra si uma causa que não é a sua. Knopfli prefere, em sua produção poética, pensar mais a poesia que a causa da libertação nacional. Mas, como Monteiro (2003) nos vai dizer, Knopfli não estava longe das articulações políticas. Mantinha relações com outros poetas, incluindo o próprio Craveirinha, de quem era amigo. Trazia consigo traços de poetas que o antecederam, traçando assim uma tradição pra si. 0 que aconteceu foi uma escolha de caminhos literários diferentes daqueles que buscavam uma identidade nacional.

Diz Knopfli:

Não sou eu que tenho que falar ou protestar, fingindo, fazendo batota na situação dos contratados. Fingindo, mas não é o fingir poético...

[...] Eu não posso assumir dores que não sinto. Eu posso reconhecer uma injustiça social larguíssima ou uma injustiça mais que social, que é a injustiça da situação colonial, que não direi que era criminosa, mas que era anómala - que é uma coisa de que me 
apercebi muito cedo, na adolescência, como é que é possível a existência de colónias, como é que há povos que têm dependências e que governam outros povos - mas eu não posso vir falar do ponto de vista dos injustiçados, só do meu ponto de vista.

Aqui, percebemos que ele de fato não se alinha, não assume essa literatura nacionalista. No entanto, ao classificar como não criminosa a situação colonial, acaba se contradizendo. No período anterior ele destaca que era uma situação injusta, portanto, que deveria ser corrigida, mas chamar de anômala a esta situação é simplificar demais as coisas. Essa contradição que existe entre o discurso que o poeta faz sobre a obra e sobre a obra em si, que supera em muito esse discurso pelas suas possibilidades de leitura. Não fazemos uma defesa do caráter de Knopfli. Isso não nos cabe julgar, mas defendemos uma leitura mais honesta de sua obra, uma leitura que leve em conta outros aspectos além do ideológico que estão muito presentes em sua obra. Desse modo, quando Mendonça recorda Valéry ("O homem que fez a obra não é o homem que a obra faz supor"), não podemos deixar de concordar. Porém o homem que a autora supõe também não é o que fez a obra. A oposição criada em seu artigo entre os dois poetas não existe. Knopfli não é contra a instituição da nação, não está em cima do muro a ponto de esperar definir-se um lado vencedor (como se pudesse haver um lado vencedor) para apoiar. Knopfli pensa em sua poesia a poesia, a arte de fazer versos. Assim, o tom principal nos poemas em que satiriza a produção poética de cunho ideológico é justamente o de avaliar a sua qualidade e o impacto que causavam.

O seu lugar de enunciação é muito complexo, já levantamos essa questão anteriormente. Destacando o período final dessa citação, tudo parece ruir para Knopfli. Ele reconhece a anomalia e a injustiça da situação colonial, mas não sofre com ela, isto é, ele não está em meio aos injustiçados. Sua posição social, sua ascendência, entre outros fatores, não permitiram que ele sofresse da mesma injustiça que a maioria da população sofria. Quando o poeta diz que não pode falar do ponto de vista dos injustiçados, mas apenas do seu ponto de vista, temos de ter em mente que ele não falava a partir do lado oposto a esse. A sua escolha de falar sobre outras coisas não constitui uma afronta ao discurso dos injustiçados. Mas pela adoção desse critério poético, o de ser honesto consigo e poetizar apenas as suas vivências, sua poesia toma outro rumo. Reflete sobre a própria poesia, sobre sua essência, sobre o ato de fazer versos. 
A confusão está sempre nessa oposição que se cria entra a poesia de Knopfli e os ideais nacionalistas do período revolucionário. 0 fato de o poeta enunciar-se em primeira pessoa do singular o faz ser temido. No entanto ele não ataca a revolução, em nenhum momento demonstra ser a favor da colonização. Não se trata, portanto, de um agente da direita que visava minar todo o movimento revolucionário com seus versos "egoístas". Ao encararmos esse fato, a oposição aparente se desfaz. Knopfli apenas traça pra si caminhos diferentes, filtrados por sua vivência em África e pelas suas referências culturais, provenientes, quase todas, dos espaços dominantes, como o europeu ou o anglo-americano. Em “Disparates seus no Índico”, Knopfli diz: “ainda emparceiro com o Zé Craveirinha,/ o branco e o mulato, verso e anverso/ do mesmo cotidiano". Esses aspectos o impedem de declarar-se nacionalista, mas não de se dizer africano e assumir como pátria somente aquele território ao qual ele sempre deveu respeito e honrarias, o denominador comum entre ele e Craveirinha, a língua portuguesa.

Em relação a Craveirinha, Knopfli completa:

O José Craveirinha tem uma importância na África de língua portuguesa a que eu não posso aspirar, nem deveria mencionar. Não sou mulato, não sofri na carne as humilhações, o preconceito a discriminação... 0 que é que pretendiam, quando vinham lá com essa história de influência, a falar deste e daquele como fontes, geralmente moçambicanas, onde eu ia beber a de inspiração? Que eu viesse fingir tudo isso? Como é que eu posso fingir em verso o negro humilhado que não sou?

[...] Para essa preocupação do politicamente correto, estou-me nas tintas. (Knopfli, APUD MONTEIRO, 2003, p. 27)

Pedimos aqui licença para um parêntese levemente extenso. Optamos por recortar o mínimo possível as falas de Knopfli. Não queríamos que elas apenas satisfizessem as nossas necessidades de estudo de forma conveniente. 0 que Knopfli fala sobre sua obra é sempre complicado e aparentemente contraditório. Sua obra une dois mundos de uma forma bastante harmônica e complexa. No entanto, nas suas entrevistas, ele revela-se mais tendencioso, tentando escapar às armadilhas de um falso moralismo, de algumas definições literárias, políticas, entre outras, e acaba justamente por se posicionar. Assumindo assim, nas entrelinhas de tudo o que diz, um comportamento pequeno-burguês citado por Fátima Mendonça (2002). Mas cabe ressaltar que essa também é uma posição a que ele não se nega. Em suas entrevistas fica claro de que ele 
era plenamente consciente de sua posição social. 0 que, talvez, não soubesse é o que implicaria essa posição.

Em entrevista a Patrick Chabal, Knopfli assume a retirada de 24 poemas em português do livro Reino submarino. Houve também a omissão de alguns poemas em inglês. Knopfli cita dois motivos para tal recorte do livro: ou eram ruins ("não prestavam"), ou eram nacionalistas, tinham uma relação direta com o referente africano. Isso se deu, nas palavras dele, "talvez porque eu pensasse, discretamente, que estava a usurpar um mundo que não é o meu pelouro, que não é do meu direito". Knopfli martela bastante essa tecla, não se sente no direito de falar sobre uma dor que não é sua. A sua dor é quase às avessas, como no episódio em que relata ter presenciado Noêmia de Sousa ser esbofeteada e ele não, pelo simples fato de ser ele branco.

Mendonça parece, dessa forma, não fazer um artigo sobre poesia, mas sobre história ou, antes disso, o caráter ideológico de sua crítica parece quase suplantar o literário. Em favor da temática nacionalista de Craveirinha, a autora enterra todo o trabalho formal desenvolvido por Knopfli. Não há sequer uma menção à reflexão sobre os aspectos formais de Knopfli ou de Craveirinha, somente ao apelo que fazem ao dizerem-se moçambicanos ou não. E Knopfli não o faz. É mesmo filho de Próspero. Está num "país dos outros". Mas escolhe o continente africano para descobrir, para situar sua produção. 0 recorte adotado por Mendonça dos poemas de Knopfli apenas atende às suas necessidades na medida em que esconde os outros atributos de sua poesia. A última frase do seu artigo: "Porque a história da literatura moçambicana é também a história da sua revolução". Há aqui uma confusão entre os estudos culturais e os literários. Obviamente há intercursos da história na literatura e vice-versa. Mas tomar somente os temas históricos, ou privilegiar determinados temas em detrimento das características que se destacam na poesia, seria o mesmo que não reconhecer o valor de um Machado de Assis, para ficarmos somente na língua portuguesa, caso nos apegássemos somente à sua temática e não aos recursos literários que ele utiliza para dar aos seus escritos o tom que dá. Machado também não está livre de seu tempo, escreve sob o peso histórico de seu contexto, no entanto, não é reconhecido por esse fato, senão pela sua habilidade literária.

Essas leituras da literatura moçambicana como paralela às correntes ideológicas da consciencialização e da reivindicação nacionalista, ou mesmo formadoras dessas correntes, como de fato ocorreu, não se dá conta, por exemplo, de que “[...] estas 
correntes inspiram-se muitas vezes em movimentos transnacionais e até transcontinentais" (MATUSSE, 1998, p. 54). Portanto, as mesmas nacionalidade e diferença que afirmam em relação ao modelo português estão diretamente relacionadas a outro modelo que não lhes são próprios. Havendo, dessa forma, uma importação, a substituição de um modelo de governo por outro que, a princípio, seria o ideal. No entanto, esses dois modelos ainda continham um traço comum. Eles eram importados, isto é, tinham sua origem em outros países. Não menosprezando os movimentos endógenos em Moçambique, mas estes, a princípio, tiveram pouca força, no sentido de que não modificaram muito a cartilha do modelo que seguiam.

Voltando ao foco do estudo de Mendonça, o conceito de nação do Knopfli é de fato confuso. Principalmente porque ele não existe nos moldes em que é procurado. A nação de Knopfli é algo que não é da ordem do nomeável. Ele não faz, portanto, parte dos que defendiam um nacionalismo, Knopfli prefere a sua Pátria à essa nação. A pátria, nesse caso, refere-se ao local ao qual o sujeito nutre um sentimento de pertença. Já vimos que assumidamente, a Pátria de Knopfli é a língua portuguesa ("Pátria é só a língua em que me digo").

Assumindo o fato de esse conceito de nação buscado pela autora do artigo não existir em Knopfli, o estudo passa a ter simplesmente a função de invalidar o discurso Knopfliano. Desrespeitando a obra do autor que nunca pretendeu assumir essa nação em seus versos e ignorando o que de fato ele fazia, além de não entender que essa literatura mais subjetiva estaria justamente a caminho, antecipava a modernidade na literatura moçambicana. Um exemplo, podemos encontrar no poema que segue, inserido em Mangas verdes com sal:

\section{PROPOSIÇÃO}

Falo de outro país singular, do perfume aloirado e desse sabor a pão matinal.

Falo, na distância, de distâncias quietas recortadas no zumbido oloroso de casuarinas azuis.

Falo de paisagens ternas e sombrias, simétricas 
como parques e losangos.

Trago notícias de outro clima pairando em luz e pólen, em suaves ardências de especiaria.

Falo de outras vozes estranhas, de murmúrios e ruídos indiscerníveis, dos pequenos ardis do silêncio.

Falo de corpos ágeis e elegantes como gráficos que se amam sem paciência.

Falo de um céu onde estrelas serenas navegam presságios e do refúgio em uma outra dimensão inusitada.

Falo da beleza das coisas simples e elementares: a água, o pão e o vinho.

Iludindo o espanto de viver falo de estar vivo e desse outro inventado país, singularmente habitado, fora da possibilidade de habitação.

Como em raras ocasiões, podemos ver aqui Knopfli falar de um país. Mas não é um país qualquer. Sempre ligado à palavra "outro", esse país e suas paisagens são sempre diferentes das que Knopfli parece ter diante de si, mesmo que seja exatamente igual. Desta maneira, o poeta nos vai contando como encara o espaço circundante e também o que escreve. Reduzindo a coisas essenciais ("a água, o pão e o vinho") o que quer dizer, ele fala de "estar vivo", isto é, de sua experiência que, como vimos frisando, é o elemento essencial de sua poesia. Falando disso, também se fala de um país, habitado impossivelmente pelo sujeito. Ora, é claro que uma leitura meramente biográfica desses versos finais tiram reduzem o brilho do poema, porém não podemos deixar de fazer a relação com o sujeito empírico, com a situação de Rui Knopfli em Moçambique. A relação que estabelece com o espaço é uma relação impossível tendo em vista que ele não pode conjugar os aspectos culturais locais e a sua experiência. Mas há aí também outro fator importante. 0 sujeito cria um país, ele o inventa. Afinal, iludindo o espanto de viver ele 
fala de estar vivo, criando uma vida dizível. Da mesma maneira, ele inventa um país, mais uma vez construindo a ponte que o coloca no mundo (CARREIRO, 1998). Matusse (1997) nos diz ainda:

Se em relação a Noémia, Craveirinha, Nogar e Kalungano esse comprometimento [poético] decorre da redescoberta de uma certa essencialidade, do tom eloquentemente reivindicatório, manifestatário e combativo, da temática social explicita e pluralmente assumida, no caso específico de Knopfli, trata-se da situação fundamental do poeta moderno que é a da solidão, da afirmação da liberdade subjetiva e que está em função do sujeito que tem uma aura de conflitualidade e indefinições a envolve-lo. Estas, implicadas na sua relação umbilical e afectiva com uma determinada realidade telúrica e cultural. A escrita de Knopfli define-se, assim, pela obliquidade, pelo intimismo e pela incessante negatividade.

Assim, sua experiência diante do espaço no qual se encontra é poetizada por meio da relação que ele nutre com outra experiência, a cultural. A intertextualidade sempre presente não remete ao mesmo espaço, geográfico ou ideológico, que o cerca, mas a sua experiência não permite que poetize outra coisa senão a sua experiência. Essa é a arte poética que assumiu pra si, a de poetizar o que tiver tripas, o que lhe for visceral. 


\section{ARTE POÉTICA - A SINCERIDADE E A FIDELIDADE À PROVA}

\subsection{Indicadores de leitura}

Entendemos Rui Knopfli ter sido, portanto, um poeta que, mesmo ciente de seu contexto político e econômico conflituoso, escolheu outro tema: escolheu pensar a poesia mais que a ideologia, mais que a política ${ }^{1}$, e o fez com maestria, elevando a forma poética a um extremo de realização e, assim, antecipando, em Moçambique, características do que, na literatura lusófona ocidental, ficou assentado como modernidade literária.

De certo modo, negligenciado pelos estudiosos, ele é de grande importância para recompor a imagem que se pinta da literatura africana em tintas de "literatura de resistência", de luta contra o colonizador, no que tange ao período das guerras de libertação, mais especificamente o caso da poesia moçambicana. Lembrando que nos referimos ao período de produção de Rui Knopfli (do final dos anos 1950 ao final dos anos 1990).

0 poeta precisou defender e afirmar muito a sua poesia, por conta do que vimos discutindo desde o início deste trabalho, isto é, por que a crítica costumeiramente cauterizava não a qualidade de seus versos ou algo assim, mas, principalmente, a sua validade em meio a produção poética moçambicana. A interditar ao poeta determinados

\footnotetext{
1 João Guimarães Rosa teria adotado semelhante posicionamento político, no Brasil, como o diz em entrevista: "Embora eu veja o escritor como um homem que assume uma grande responsabilidade, creio entretanto que não deveria se ocupar de política; não desta forma de política. Sua missão é muito mais importante: é o próprio homem. Por isso a política nos toma um tempo valioso. Quando os escritores levam a sério seu compromisso, a política se torna supérflua. Além disso, eu sou escritor, e se você quiser, também diplomata; político nunca fui" (LORENZ, 2009, p. 62-63). Ainda elucida adiante: para ele, política consistiria em assumir as próprias escolhas e levá-las a termo e ao longe: os que optaram por serem escritores deveriam, então, por coerência política, ocupar-se da palavra.
} 
assuntos ou formas, a crítica incidia sempre no sentido de desqualificar seus versos apenas pela escolha prévia do caminho literário diverso que fez. Mas, afinal, e essas talvez sejam as grandes questões deste trabalho, o que é permitido a um poeta, e o que não é? Sobre o que pode ele escrever? Quem pode legislar sobre isso? Como ele pode escrever? Quem, de direito, o subscreve? O que pode (qual sua potência) o poeta fingir?

Knofpli, sempre que fala de sua obra, traz à tona o elemento da experiência, da vivência, para fazer poesia. A isso, é bastante fiel. Assim, quando fala dos outros poetas, seus contemporâneos, não os diminui; o que faz é apenas se negar a reproduzir o seus modelos. Afinal, as vivências deles foram inequivocamente diferentes - já discutimos os aspectos biográficos de Rui Knopfli atinentes ao fato de ele não ter sofrido os mesmos problemas que, por exemplo, José Craveirinha sofrera. Dessa forma, a poesia de teor ideológico mais carregado ficou à margem da sua produção: Knopfli não quis assumir, como também já dito por nós e pelo próprio poeta, uma dor que não foi sua.

Por essa razão, por não acompanhar o rebanho de literatos e críticos da época, seu gesto poético não era "naturalmente" tido como tal, ele precisou sempre afirmar sua poesia. E não o fez simplesmente em entrevistas ou discursos outros sobre a própria obra, senão também nela própria.

Carreiro (1998) diz:

A metapoética e a interacção de diversos discursos em Memória Consentida [coletânia que reuniu a obra produzida por Knopfli entre 1959 e 1979] ao mesmo tempo [em] que servem o processo de autognose do autor encenam outras presenças entre as quais se inclui a do leitor. (p. 68)

Dessa forma, Knopfli nos vai dizendo não apenas como escreve, mas também como deve ser lido. Processo muito característico de sua obra e reafirmador, já no próprio ato de escrevê-las, do sugerido em suas tentativas de arte poética - o que talvez seja seu maior critério poético: a fidelidade a si mesmo e à sua experiência.

Ainda nas palavras de Carreiro:

A par da dificuldade confessada dos críticos em situar esta produção poética [de Rui Knopfli], é o autor quem, numa condição de autoconsciência, em duas artes poéticas e vários poemas de 
idêntica função, reflecte sobre a sua escrita e constrói a ponte que o coloca no mundo. (p. 63)

0 poeta incumbe-se, portanto, também o papel de delimitador de sua própria crítica, como senhor de sua fala e contra uma leitura equivocada de sua obra.

Vamos analisar alguns casos dessas tentativas de delimitação da leitura e, mais adiante, as suas tentativas de arte poética, embora esses dois casos, por vezes, interliguem-se de forma indissolúvel. Elas aparecem, por vezes, para marcar uma diferença com relação aos outros poetas de seu contexto. Em “Ars Poética 63", por exemplo, ironiza-se a poesia de cunho coletivo. Sua opção é sempre por uma poesia que o diga a si próprio, que fale da sua experiência, ainda que impessoal. Sua confecção de poesia sempre supõe explicitamente um filtro, uma limitação: o próprio olhar e sua experiência. E, por isso, por esse viés da urgência em experienciar as situações, Rui prefere falar somente da sua experiência, e não se vale do sujeito coletivo de outros poetas. A respeito da sua experiência, Knopfli diz:

Vamos a pegar num caso muito simples, que é o caso, por exemplo, de um poema do Craveirinha sobre a vida do subúrbio. É toda a humilhação que vem do racismo, e que ele põe com uma ironia... [...] É a destilação de uma vivência, porque se isto não tiver tripas, não é nada. (apud. CHABAL, 1994, p. 189)

Assim, defende o teor da sua obra sem condenar a obra de cunho ideológico. Já muito falamos que a poesia de contestação, de resistência, épica, com sujeito coletivo, não é realizada por Knopfli, mas isso se deve, em alguma medida, à falta da experiência do poeta nessas questões e, em maior medida, à escolha que ele faz em não agregar à sua poesia nada que fuja à sua experiência.

Essa é a forma por ele elaborada de fazer versos, é sua arte poética, praticada de forma muito honesta e fiel. Prefere dar valor às suas vivências e as elege como critério temático para sua obra. Assim, para Knopfli, quando Craveirinha escreve seu poema, condiz com sua condição, tendo em vista sua experiência. Mas Knopfli não pode assumir a mesma posição, isto é, partindo de vivências diferentes, sua obra não poderia ser senão diferente. Ele escolhe falar de outras coisas para não fingir, para não forçar uma poesia que jamais seria a sua. Por isso, num poema engagé de Craveirinha, encontra-se muito de "tripas" que, para Knopfli, o legitima. Em qualquer poema de Knopfli, também se encontram "tripas", mas com cicatrizes diferentes. 
Destacando sempre essa experiência em seus versos, que não se posicionam, como alguns críticos gostam de insinuar, em cima do muro, Knopfli vai moldando o seu leitor, definindo os seus próprios indicadores de leitura.

A primeira tentativa talvez seja o já citado poema "Naturalidade". Nele, o poeta anuncia que é certo trazer consigo algo de europeu, mas, a despeito disso, o sujeito assume-se africano, mesmo com os problemas já levantados anteriormente quanto às imagens de que o poeta se vale para fazê-lo. Aqui, o sujeito já assume estabelecer, sim, elos com a cultura europeia; o contrário, aliás, convenhamos, seria uma indignidade a qualquer poeta, escritor de livros, afeito a formas tão solidamente europeias, apesar de, no entanto, tal indignidade não ser rara. Rui Knopfli concorda que os versos dele tragam consigo referências a essa cultura, mas, acima disso, ele se sente pertencente à África. 0 que seria uma aparente contradição, nada mais é do que uma mistura de culturas. À guisa, por exemplo, do que faz o nosso Oswald Andrade em sua antropofagia.

Knopfli usa uma boa dose de ironia para também marcar esse seu lugar de enunciação tão peculiar e também para reafirmar a diferença em relação à poesia que se fazia no momento. Ele segue por um caminho paralelo, falando de outras vivências, de outras experiências. Em uma de suas tentativas de escrever uma "arte poética”, Knopfli discorre sobre sua poesia. Não apenas sobre como ele a produz.

O título do primeiro poema de Mangas verdes com sal, de 1969, apontado como o primeiro livro de sua maturidade poética assinala a insistência na busca por definir essa "arte poética", insinuando ser esta a sexagésima terceira tentativa de escrita de um poema com essa temática.

\section{ARS POÉTICA 63}

$[\ldots]$

Pode começar por uma palavra bonita, coisa rara e difícil. E arriscada: nunca se sabe o que virá depois que pode ser bem pior e fracassar. Há quem comece com irmãos, o que tem vantagens inúmeras, desde as garantias de escola às conveniências e conivências do correligionarismo fiel que assegura um público bastante certo, embora pouco amante de poesia e, de ordinário, pouco esperto. 


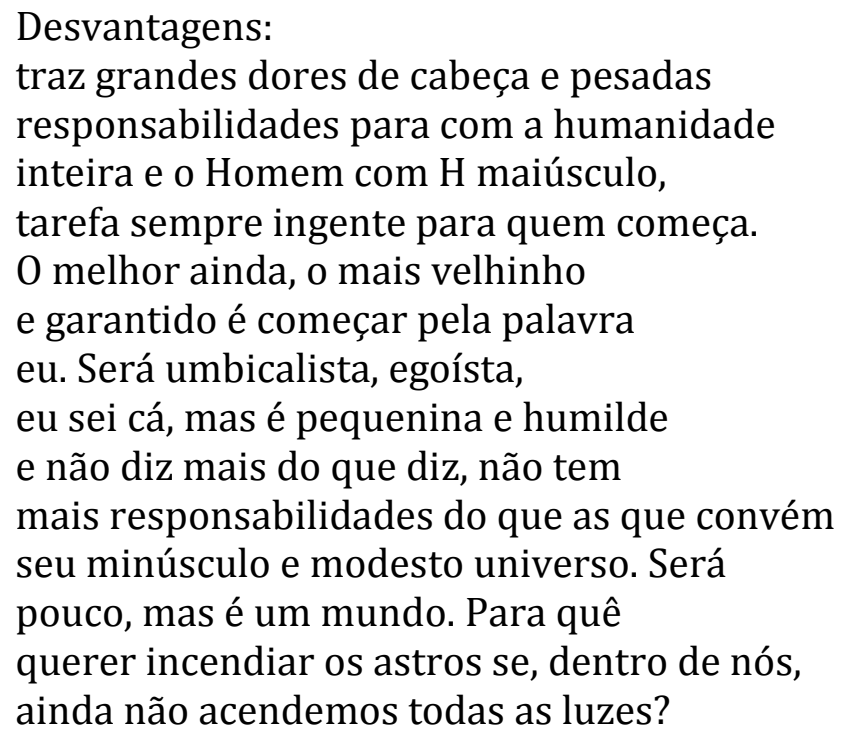

A todo o momento, Rui desestabiliza a poesia de teor ideológico, ou engagé, como ele mesmo denomina em uma de suas entrevistas. A ironia é uma grande estratégia para alicerçar essa postura. No poema "Ars Poética 63", há uma alusão a esse tipo de poesia: "Há quem comece com irmãos". Knopfli discorre a respeito do que isso ocasiona, o que proporciona e ainda sugere a abrangência do público, ou seja, a receita da aceitação pra quem, naquele momento, escreve dessa forma. No entanto, querer abraçar o mundo, querer falar por todos pesa-lhe demais. Knopfli não se sente a altura da assunção de um sujeito coletivo, não se sente a altura de tal "tarefa", que se revela "ingente". Mas o peso de sua experiência e de suas leituras o faz olhar pra dentro, mesmo que de forma egoísta, como ele mesmo dirá, para escrever sobre seu universo, sobre seu modo de estar no mundo ("Será/ pouco, mas é um mundo."). 0 encerramento do poema ainda é mais emblemático na medida em que o poeta evoca a imagem da luz. Há uma crítica àqueles que querem ser grandiosos e grandiloquentes, mas que não conseguem voltar o olhar para dentro e "iluminar-se".

Seguindo essa linha, ou melhor, esse honesto desalinho por parte de Knopfli, o poema "'Cântico negro"” ataca com mais agressividade a de cunho ideológico.

\section{“CÂNTICO NEGRO”}

Cago na juventude e na contestação e também me cago em Jean-Luc Godard. Minha alma é um gabinete secreto e murado à prova de som e de Mao-Tsé-Tung. Pelas paredes 


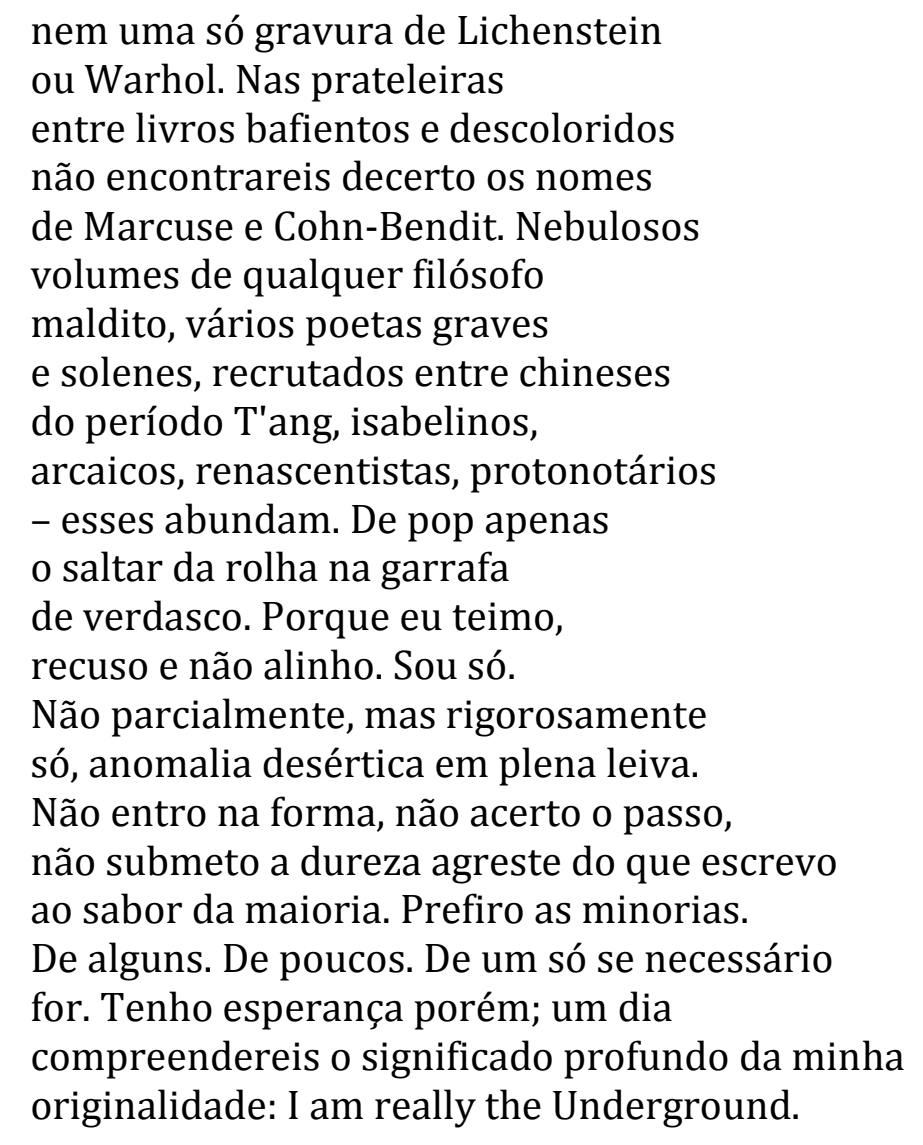

Aqui, o poeta revela o seu não alinhamento, com a negação de Mao-Tsé-Tung e de Warhol. Nega a massificação da cultura pop massificadora e também nega o posicionamento esquerdista em voga. Traz consigo a certeza de que seus versos não são também populares, não buscam com um determinado tipo de discurso angariar seguidores ou divulgar determinada ideologia. Sua poesia não se alinha, não "acerta o passo". A preferência pelas minorias, na qual ele mesmo está inserido (mesmo sendo uma minoria antes privilegiada), é latente. A essa minoria, de poucos ou de um só, é à qual pertence sua experiência, à qual toda sua vivência está ligada. Ao falar de si e da sua experiência, mesmo se quisesse, Knopfli não poderia agradar a maioria. Chegando ao extremo de que esse "um só" leitor de sua obra não seja senão ele próprio.

0 trecho final do poema revela ainda alguma esperança: a de ter aquilo que entende por "originalidade", o seu não alinhamento, reconhecido e compreendido. Ele espera que sua obra possa ser lida sem rótulos, sem estereótipos, mas apenas a obra de um poeta, desvestida, portanto, de significações que lhe são externas. 
O seu isolamento também é repleto de intencionalidade: no poema, a imagem de um "gabinete secreto" é usada para definir a alma do sujeito, que escolhe o que vai guardar na alma ou não.

Acima de tudo, temos de destacar a referência clara ao poema homônimo de José Régio, cujo final diz:

\author{
Ah, que ninguém me dê piedosas intenções, \\ Ninguém me peça definições! \\ Ninguém me diga: "vem por aqui"! \\ A minha vida é um vendaval que se soltou, \\ É uma onda que se alevantou, \\ É um átomo a mais que se animou... \\ Não sei por onde vou, \\ Não sei para onde vou \\ Sei que não vou por aí!
}

Assim, Knopfli recusa-se também a "ir por aí" e, desapegando-se do leque de referências que são signos políticos, assume uma espécie de "inxílio", ao qual foi condenado a princípio, definindo-se como o verdadeiro underground. 0 conceito de "inxílio", desenvolvido por Volpe ao longo, se refere à interiorização do exílio, podendo ser experimentado de maneira subjetiva, como o isolamento do indivíduo do mundo exterior, levando à constituição de um sujeito alienado das experiências cotidianas e coletivas, ou de maneira mais objetiva, através do isolamento cultural, histórico ou espacial, mas sempre no interior de fronteiras geográficas bem definidas, como a experiência da clandestinidade política, analisada pela autora na poesia uruguaia da segunda metade do século XX. Para contrapor o "inxílio" ao exílio. Assim, Miriam Volpe explicita o sentido do segundo termo fixando-o como "ex-Ílio" (cf. VOLPE, M. 2005).

As aspas no título indicam a inserção do poema e, consequentemente, do poeta português na sua obra. É bastante significativa a escolha de um poeta português, se pensarmos que todos à sua volta estavam preocupados justamente em negar as referências portuguesas, lembrando que o livro no qual está inserido o poema (Mangas verdes com sal) é de 1969. Isso só reforça a ideia de que Knopfli estava muito mais preocupado em escrever, ou transcrever a sua posição, o seu modo de estar no mundo em palavras do que em marcar uma diferença que, no seu caso, era pequena. Essa foi a sua escolha. 
Gilberto Matusse (1998), sobre o comparatismo entre autores moçambicanos, diz que:

A situação colonial de que emerge a literatura moçambicana é marcada por interações, por clivagens, por atitudes de distanciação e de assimilação ou apropriação, que implicam tomadas de consciência de ser/pertencer a um grupo e, por consequência, não ser/não pertencer a outro grupo. Como se sabe, a imagem resulta deste distanciamento e corresponde à representação do outro a partir do espaço ideológico ou social em que se situa o eu. (p. 58)

A grande dificuldade é situar justamente esse espaço ideológico de Knopfli. 0 social, nós conhecemos, filho de portugueses, compartilhava dos mesmos espaços que Craveirinha, com a diferença de ser branco. Travava discussões políticas, não estava alheio à situação do país. No entanto, seus poemas revelam outro universo, outro tipo de ideologia: a do não alinhamento, não chegando a afirmar uma anarquia, mas assumindo a fidelidade apenas consigo próprio. 0 distanciamento veio na forma da negação da poesia engajada, na vontade de trilhar outros caminhos poéticos, proporcionados por sua vivência. Já a apropriação veio através de suas leituras livres de preconceitos, principalmente dos autores de língua inglesa, como já dissemos. Knopfli assumia portanto o seu ponto de vista, principalmente no que diz respeito à arte. Vejamos um exemplo:

\section{POESIA SEM MAIS NADA}

De pequenos materiais, carinho e minúcia, algo de subtil humildade, o poeta-sem-mais-nada compõe seu verso silencioso. Enquanto isso o poeta demagógico distribui o granel das rimas em ão, em dade, em aço.

Assim, o irmão estende o braço da fraternidade no abraço que vai do coração à humanidade. Rola e estraleja farto o trovão no verso chocoalhante do poeta demagógico e o público aplaude comovido. Passada a borrasca tonitroante do verso, o céu aparece limpo e o sol sorri antigo. Na oficina escura do poeta- 


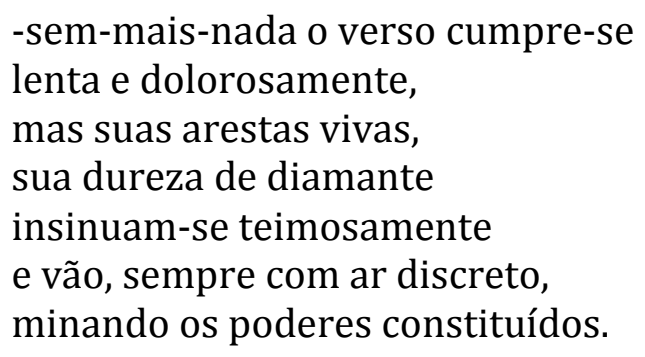

Neste poema, fica evidente o que Knopfli enxergava na poesia ideologicamente carregada. Entre os principais elementos citados por ele, a rima ocupa um lugar de destaque. Essa poesia "demagógica" apontada por Knopfli se limitaria, portanto, a determinadas formas para causar a comoção do público. 0 equívoco de Knopfli foi, no entanto, achar que após a "borrasca/ tonitroante do verso. 0 céu aparece limpo e sorri/ antigo". Já destacamos que a poesia foi um meio de divulgação da revolução e do ideal de identidade nacional. Mas mesmo com esse equívoco, seus versos que não se dobravam à vontade de uma causa, teriam maior mobilidade no terreno artístico e, por meio deles, Knopfli estaria "minando os poderes constituídos", à época, acreditamos ser essa a imagem dos poderes que influenciavam a arte no cenário político moçambicano. Ou seja, este seria um manifesto da batalha que Knopfli manteria para a defesa de sua pátria (a língua), de seus versos, de sua individualidade diante da poesia que buscava a assunção de uma identidade coletiva.

No poema "Contrição", Knopfli (2003, p. 210) comenta suas leituras e o "detractor" de seus versos. 0 poema, que vem acompanhado de uma boa dose de ironia, fala do que o "detractor" consegue rastrear em termos de intertextualidade e o que lhe é interdito.

CONTRIÇÃO

A pretexto de uma mulher de Portinari que lembra Picasso (ou Antonello?)

Meus versos já têm o seu detractor sistemático: uma misoginia desocupada entretém os ócios compridos, meticulosamente debruçada sobre a letra indecisa de meus versos. Em vigília atenta cruza o périplo das noites de olhos perdidos na brancura manchada do papel, progredindo com infalível pontaria na pista das palavras e seus modelos. [...] 
A começar pela epígrafe, em que Knopfli estende a imagem de uma mulher de Portinari e atribui a ela uma identificação com outra mulher, ou seja, algo que ele pode identificar por meio de sua experiência. Porém, essa identificação se dá com outros dois grandes nomes das artes visuais, Picasso e Antonello. A mulher de Portinari não deixa de ser criação sua, apesar de a experiência de quem a observar trazer à tona a lembrança de outras duas mulheres.

Para Knopfli, foi esse o papel que a crítica assumiu diante de seus versos. Esses mesmos "detractores" são os que buscam identificar, na sua poesia, as referências que o poeta traz de outros espaços ideológicos e culturais, ou seja, sua crítica mais circunstancial e, por isso, limitada.

Mais adiante, depois de uma listagem de referências mais fáceis de notar na obra de Knopfli, no mesmo poema, o poeta se surpreende com a perseguição desse "detractor". Vejamos:

$$
\begin{aligned}
& \text { [...] Estão-me interditas, } \\
& \text { com certos ritmos, certas palavras. Assim, } \\
& \text { não devo dizer flor nem fruto, } \\
& \text { tão-pouco utilizar este ou aquele nome próprio, } \\
& \text { e ainda certas formas de linguagem comum, } \\
& \text { desde o adeus português (surrealista) } \\
& \text { ao obrigatório bom dia! (neo-realista). } \\
& \text { Escrevendo-o quantos, sem o saber, } \\
& \text { mo interditavam apenas a mim; a mim, perplexo } \\
& \text { e interrogativo, perguntando-me desolado: } \\
& \text { - E agora, José?, isto é, - E agora, Rui? } \\
& \text { [...] }
\end{aligned}
$$

Nota-se a interdição, a crítica que "persegue", em seus versos, as referências àquilo que não partilhe da ideologia em voga. A surpresa maior surge quando há a interdição de versos, ou ideias, imagens etc., do próprio poeta. Mesmo quando o poeta encontra, por si, um meio de se dizer, encontra-se algo a lhe interditar, a pôr de lado, a isolar. Isso acontece de tal forma que o sujeito ironicamente se confunde em suas palavras com a questão levantada por Carlos Drummond de Andrade, como vemos no último verso do trecho acima. Já não sabendo se a situação é a sua ou daquele "José" que se lê em Drummond, como no caso da mulher de Portinari. 
Mais adiante, Knopfli se ri da perseguição que sofre, "confessando" a ligação com muitos outros autores. E, ainda, com outra dose de ironia, atribui a eles a riqueza, assumindo para si a figura do herói mítico Robin Hood, que roubava o dinheiro dos ricos e o distribuía aos pobres:

[...] Que, em suma, roubando aos ricos para dar a este pobre, sou o Robin Hood dos parnasos e das Pasárgadas.

A esse respeito, Carreiro (1998) comenta que:

O dialogismo textual é algo a que o escritor não se subtrai, antes, cultiva o confronto com textos alheios como forma de apurar e afirmar a sua própria escrita. [...]

A circunstância de o discurso literário ser intertextual não retira a singularidade do autor, porque «assinala a intersecção da criação e da recriação, da invenção e da crítica» (HUTCHEON, p.128).

É nesta qualidade que Rui Knopfli revela ser um leitor ávido e crítico [...] (p. 67).

Revela-se, portanto, que Knopfli não só lê a poesia das metrópoles, dos "centros" de cultura, mas também é crítico delas e escolhe pra si aquilo que melhor lhe diz, que melhor lhe representa, tendo em vista a não identificação com a poesia que se produzia em Moçambique. Mais uma vez, a antropofagia aqui é lembrável. Roubar aos ricos, isto é, ler os poetas que não estão no mesmo cerne de leituras de seus contemporâneos ou, antes disso, apropriar-se dessas leituras como Knopfli faz, e que não apenas faz, mas diz que faz, explicitamente, chegando ao ponto de demonstrar as passagens intertextuais de sua obra ao final do livro $O$ escriba acocorado, em forma de "Notas ao texto", caracteriza suas preferências literárias, suas escolhas temáticas e, ainda, reafirma a sua fidelidade a uma escrita comprometida apenas com o que tiver tripas, com o que for somente e essencialmente seu. Ele realiza a aproximação dos dois lados, trazendo pra sua própria obra a poesia europeia, mais ocidental e ocidentalizante, Knopfli conjuga poesia africana e europeia. Ele as unifica antropofagicamente.

\subsection{No jardim, apenas flores}


Outro meio que o poeta encontra para delimitar a leitura de seus versos, além das "artes poéticas", é a imagem da rosa, a qual, a princípio, Knpfli marca como pertencente a um espaço específico, ou seja, como incorporadora desse espaço. Depois, ele a desveste, desnuda, limpa de tudo aquilo que não seja rosa. E, por fim, depois desse processo, a rosa pode, novamente, ser usada por ele como elemento poético, como imagem a ser elogiada em sua essência primeira, esvaziada, portanto, da personalização de um determinado espaço, cultura ou algo que o valha. Assim, Knopfli foge às questões ideológicas que não lhe são características, e mais do que não falar, ele diz que não quer falar, demonstra isso.

Vejamos, pois, como se dá esse processo retornando ao poema "Naturalidade":

Rosas não me dizem nada, caso-me mais à agrura das micaias e ao silêncio longo e roxo das tardes com gritos de aves estranhas.

Sempre podemos contar com uma diferenciação espacial nos versos de Knopfli. Nunca assumindo uma posição nacionalista moçambicana, mas sempre em favor de uma posição africana. No caso acima, as rosas, imagem recorrente da poesia, não dizem nada ao sujeito. No entanto as micaias já lhe casam bem por serem frutos do continente africano e, portanto, muito mais próximas e significativas ao poeta. Isso sem contar o fato de ser um espinheiro, o que está também presente nas rosas através do caule. 0 poeta poderia dizer que lhe casam bem os espinhos, e não as pétalas, mas a marca da diferença não estaria tão evidente. As micaias, além de trazerem consigo a dureza de espinhos e o aspecto sofrido quase como os cactos, ainda trazem outra característica comum ao poeta: a pertença à África. Ora, sendo assim, rosas e micaias são imagens representativas de dois espaços entre os quais Knopfli circula. Julgado europeu pela sua crítica e afirmando seu amor ao continente africano, Rui resume esse conflito e aponta para sua preferência usando a imagem das flores.

Aproveitando a temática das rosas e micaias, podemos também citar outro poema:

POEMAZINHO REACCIONÁRIO PARA USO PARTICULAR

Tenho uma flor. Pálida.

Não uma flor difícil, 


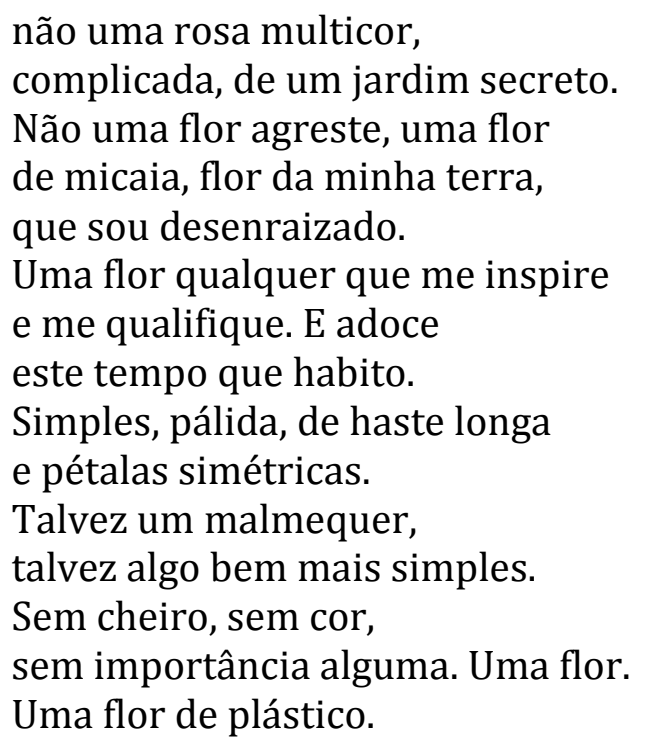

Aqui, o poeta vai além. A flor de plástico, que seria já uma imitação, é imitada. Quase como num jogo de espelhos. Mas, pouco a pouco, o sujeito vai destituindo a flor de sua simbologia ao recusá-la sob algumas formas, ao recusar alguns tipos de flores. 0 título irônico do poema pode dar, aos desatentos, um tom jocoso à leitura, no entanto, o poema é reacionário, logo reage a algo. $\mathrm{E}$, nesse caso, reage às rosas. A micaia, mais uma vez, é referência e preferência, em relação à rosa, a salientar novamente a diferença espacial e o apreço pela forma poética. Quando o sujeito se diz desenraizado, expõe o drama de seu lugar de enunciação, o drama de viver num "país dos outros", em que mesmo sendo as micaias flores de sua terra o sujeito poético está "desenraizado". É um complexo jogo de palavras que busca elucidar o seu lugar de enunciação e também tenta desvincular de sua figura, do sujeito que se confunde com o poeta, a associação a determinado espaço, dando mais valor às palavras.

No entanto, a flor de plástico ainda é a escolhida, em detrimento da micaia. Considerando o local de enunciação, a flor de plástico é tudo o que Knopfli pode cantar. Ele é um estrangeiro numa terra que é a sua, paradoxo imposto de tal forma que sua poesia não pode cantar a verdadeira flor, mas somente sua imitação. Essa é a flor que pode qualificar sua posição de não alinhamento, uma reação ao que lhe dizem e ainda revela a consciência de Knopfli sobre seu contexto e sua condição. Outro fator importante a essa leitura é o despojamento dos valores atribuídos às flores, não uma rosa, nem a micaia, mas uma flor sem cheiro, sem cor, pálida, livre de simbolismos, restando ao poeta somente a mera imitação, o mero fingimento poético, retomando o 
anseio de que as palavras sejam "não uma exclusiva volição// de ser ou de significar; se conduzam, porém,/ de tal forma que, em significando, sejam e, sendo,/signifiquem não sejam ou signifiquem, mas que "sendo, signifiquem" (p. 427).

Já sabemos que Knopfli não era apático ou indiferente quanto às questões políticas, como demonstrou Fátima Monteiro (2003). Ele conhecia e mantinha contato e discutia as questões políticas de Moçambique com Craveirinha, Noémia de Sousa, entre outros ativistas políticos. Trazendo entrevistas com o autor e contando sua trajetória de vida, a autora nos mostra que, apesar dessas participações em discussões políticas, Knopfli poetiza de um lugar muito complexo: "Um sujeito que, sendo anticolonial solidário a Caliban, e pós-colonial na autorrepresentação de si, se sabe no entanto racial e culturalmente descendente de Próspero". (p. 58)

Chegamos agora à terceira fase do tema da rosa, em que, destituída, enfim, de tudo o que lhe fora atribuído, a rosa pode, finalmente, ser ela mesma.

\section{A DESCOBERTA DA ROSA}

“Rosas não me dizem nada..."

Dez anos de poesia, fora a gaveta e descubro que, a não ser ocasionalmente e em ar de troça, jamais me debrucei deveras sobre o tema da rosa. De resto eram pra mim, creio, marginais as flores. Vícios de formação e juventude, uma tão intensa preocupação do humano que olvidei a discreta angústia da rosa. Outros, não o ignoro, nela tiveram seu princípio para a deixarem depois esquecida entre as páginas de um qualquer livro, tão cheios eles, de ternura e simpatia fraternais, coisas que já eludem este coração envilecido. Salvo o devido respeito por tudo quanto é útil e estimável na terra, faltam-me o tempo e o ânimo para as empreitadas mais ingentes. E o pouco que me sobra tenciono aplicá-lo em tarefas humildes como o cultivo destes versos, algum súbito amor inadiável e a lenta e minuciosa descoberta da rosa. 
A princípio, o "ar de troça" com que se lembra o sujeito de ter tratado o tema da rosa invoca os outros dois poemas cronologicamente anteriores a este. E este "ar de troça" consiste justamente em desnudar a palavra de sua simbologia.

"Vícios de formação e juventude" o fazem preocupar-se mais com o humano, com o individual, deixando o tema da rosa quase interdito pra si, tendo em vista que, ali, ela não estava ainda livre desses outros significados. Isso o impedia de tratá-la como um objeto de sua poesia, impedia de cultivá-la.

Assim, finalmente, liberta de tudo aquilo que lhe fora atribuído em termos de simbologia, a rosa pode ser descoberta. E esse é um processo minucioso por parte do sujeito. 0 verbo "cultivar", ligado aos versos que produz o sujeito, aproxima-o da própria rosa. Cultivar os versos seria o caminho para descobrir a rosa, atribuindo assim, um novo significado à rosa, a poesia. Somente retomando, portanto, os aspectos significativos primários da rosa, ou seja, sua gama de significados essenciais, o poeta pode fazer uso da palavra.

Assim, em toda a sua obra, Knopfli tenta por diversas vezes desnudar-se, livrarse, um pouco que seja, dos seus elementos bibliográficos, para, transformando-os em poesia, desnudar-se a si próprio, livrar-se de simbologias atribuídas, assume a ligação com outras culturas, mas, ao afirmá-las, ele também as nega. Afinal, como dissemos, ele apropria-se antropofagicamente delas. Ele as traz para o cotidiano africanomoçambicano e, com tudo isso, compõe uma obra muito instigante em território moçambicano, a inspirar pensamentos e interrogações outras em nós.

Se o poeta deve ou não ser incluído no rol dos poetas moçambicanos, ou seja, se sua poesia é característica de Moçambique ou se foi apenas uma coincidência a sua produção, e nem toda ela, ser realizada em território moçambicano, não é objeto de estudo deste trabalho, mas apenas que esse trabalho seja reconhecido pelo que ele é. Justamente na negação, no desalinho, no sentido contrário do que se produzia à época. 


\section{VÁRIOS CAMINHOS PARA UM SÓ DESTINO}

Quatro dos livros de Knopfli iniciam-se por tentativas de arte poética, entre outros tantos poemas de mesma função que se acumulam ao longo de sua obra, indicando certa obsessão do poeta em abarcar em versos o modo pelo qual ele faz versos, como se dá essa produção, sobre o que ele quer falar. Assim, dizendo sobre o que ele quer fazer versos, também vai insinuando como quer ser lido. Recusando a poesia mais carregada ideologicamente em favor de uma causa específica, Knopfli dá ênfase ao trabalho poético, à composição poética e à própria poesia como temáticas características de sua obra, além, é claro, de uma defesa de um local de enunciação diferente do que o praticado em seu contexto.

Um dos casos marcantes nesse modus operandi é o do livro $O$ escriba acocorado. Começa com uma "Proposição", anunciando a que veio o poeta. Os poemas são numerados: sugere uma ordenação. Essa ordenação se fará ainda mais notável quando nos depararmos com o poema final, que, retomando como o primeiro e a ele evidentemente relacionado, leva o título de "Posposição".

A propósito do poema de abertura, ele descreve a imagem de um poeta velho observando uma cidade desgastada e em decadência. Os versos não cerram sua totalidade dentro das estrofes, de modo a solicitar leitura corrida.

Vejamos agora o primeiro poema de $O$ escriba acocorado:

\section{PROPOSIÇÃO}

Servidor incorruptível da verdade e da memória escrevo sentado e obscuro palavras terríveis de ignomínia e acusação. De pouca ternura também. Na penumbra deste recanto anónimo, a aranha sombria entretece na quebradiça

baba lucilante o fabrico da História. que há-de ler-se. Animal cauteloso, retraçando um velho ritual, seus gestos assumem, ainda assim, a gravidade hesitante do risco calculado. Séculos de aprendizagem me ensinaram uma humildade serena. Escrevendo 
escrevo-me, reconciliado com os agravos suportados e as ofensas infligidas. Os olhos que mal vêem, viram e não querem esquecer. E o que não vêem agora, descortina-o a exercitada

sabedoria de quatro sentidos despertos. Enganei e fui enganado à porta do templo; No deserto aprendi com a sede a parcimónia. A um só tempo três mulheres amei e a nenhuma delas deveras amava. Convicto

lhes menti; foram felizes. Eu não. Por isso sofri lendo-lhes nos rostos a exaltação ardente de suporem-se amadas. Traindo, sucumbi também aos ardis de Atena. Traído, duplamente traído, a traição que me vitima

em traidor me erige. Hesitações e lapsos da vontade, por hábito se mudaram em outras tantas vilezas traições. Venho de longe, no verbo latino, no axioma Grego, fui escravo no Egipto, homens

morreram a meu lado e vendo-lhe os olhos agónicos e súplices, voltei horrorizado o rosto. Aprendi depois o convívio com a morte e que mortos são apenas gente que nos espera dormindo. Engendrei filhos, plantei a árvore, ergui pedra

a pedra uma morada. No termo devido, aqueles dispersaram-se a um destino vário. Breve me quedava a contemplar os calcinados escombros da casa que os vira crescer e partir. Imóvel, assomo agora ao limiar maldito onde,

a fugitiva luz que estremece e, roxa, coagula, velhos que ninguém conforta, hesitam e aguardam, repartindo em partes iguais menos pão do que amargura resignada. Esta é a sequência das imagens quebradas que o sol

descarna, fragmentos de um corpo cuja acabada totalidade se perde no torvo domínio do indecifrável. Em cada reflexo cintila a verdade e todos reenviam ao mais espesso negrume. Sorriam pois, falsos deuses, ao meu penoso e árduo linguajar; que as glórias efémeras cumpram o seu destino meteórico e, no azul, a esfera 
retenha o escorreito traçado da sua curvatura.

A História que há-de ler-se é por mim escrita.

Anonimato igual nos cobrirá. A estas palavras não.

Escrevendo na penumbra, o poeta é uma aranha, tecendo a teia da história. Mais que tecer, a aranha entretece, o que reforça o destaque dado ao trabalho, ao labor de fazer versos. 0 trabalho de entretecer da aranha, portanto, encontra espelho no trabalho de escrever versos, e a teia ainda conta com a característica de ser visceral, como são também os versos de Knopfli (cabe aqui lembrar mais uma vez uma fala já citada do poeta: "porque se isto não tiver tripas, não é nada"). E ambos trabalham em um "recanto anônimo", a partir de um lugar apartado das vias principais. É só lembrarmos o lugar de enunciação do poeta já tantas vezes aqui evocado, para entendermos este recanto anônimo.

A história que aranha e poeta entretecem não é de agora, e é dita em "verbo latino" e em "axioma grego". Essas imagens infligem, além da referência à origem da língua, na qual se é dito e que, no poema seguinte, Rui assume, literalmente, como pátria, uma referência a toda a História que o precede, a tudo o que já foi escrito desde os tempos de Grécia e Roma. Knopfli, desde seu primeiro poema, tenta escrever-se na história e, assim como a aranha faz a sua teia que permanecerá e, na qual, "há de ler-se" o vestígio de sua passagem, o poeta tenta deixar pra trás os seus versos como marcas na História.

Ele observa a aranha, a escreve escrevendo-se, falando de si, com suas entranhas, as já mencionadas "tripas". Há, ali, uma "poesia de subjetividade lúcida e autovigiada. Ela é também e declaradamente o memorial privado de uma história coletiva" (REBELO, 2003). O próprio Knopfli traz, consigo, essa consciência expressa nos versos finais ("A história que há de ler-se é por mim escrita/anonimato igual nos cobrirá. A estas palavras não.").

Em O corpo de Atena (1984), Rui Knopfli começa com "Notas para regulamentação do discurso próprio". Nesse texto-poema, fica muito difícil delimitar as fronteiras entre o que ele diz a si mesmo e o que está ali escrito para os outros, para quem o lê. Ele se equilibra nessa fronteira dividindo o texto-poema em três momentos e nele apontando para os limites de sua própria poesia. Delimitando-se a si próprio, dessa maneira, o sujeito visa também a delimitar as leituras possíveis de sua obra, ou seja, ao 
aproximar o leitor de seu fazer poético, Knopfli o envolve num processo de leitura que não pode ser outro que não aquele descrito por ele. Assim, portanto, ele "constrói a ponte que o coloca no mundo" (CARREIRO; 1998, p. 63)..

Na última parte, mais especificamente, o sujeito faz um apelo para que sua obra permaneça fiel a uma verdade, a sua verdade, mesmo quando transformadas, as palavras que usa para dizer essa verdade, pelo seu "amor das palavras".

Que, transformando-as em fim, o amor das palavras não corrompa e destrua o amor da verdade.

Abro espaço aqui para a autorreferência que faz o poeta. Em seu primeiro livro, há um poema cujo título é, justamente, "Amor das palavras”. Nesse poema, fica evidente a relação de Knopfli com as palavras. Nos dois primeiros versos ("Amo todas as palavras, mesmo as mais difíceis/ que só vêm no dicionário."), o poeta estabelece a sua relação com as palavras pelo que elas são, e não tanto pelo que significam, no entanto, mais adiante, ele nos dirá que aprendeu com o dicionário novos atributos para as coisas do mundo. Elas ultrapassam o simples fato de existir, passando a significar, traduzindo em imagens o que não se pode escrever ("O dicionário ensinou-me mais um atributo/ para o sabor de teus lábios./ São doces como sericaia."). Dessa forma, Knopfli assume a sua preocupação maior com as palavras, com a poesia, com a tradução em palavras do mundo que o cerca, por meio do amor que nutre por elas, isto é, encarnando "amor das palavras" em "fazer poético".

Esse desejo é retomado, mais adiante, no texto-poema de abertura a $O$ escriba acocorado. E, ainda, Knopfli revela mais uma vez a vontade de que seus versos não sejam apenas um jogo vazio de palavras, como podemos ver no trecho que segue:

Que a prevalência do jogo gratuito me não arraste e me seja concedida a benfeitoria da recusa, em todas as circunstâncias e por ilimitado prazo.

Assim, o poeta reafirma o que vimos dizendo ao longo desse trabalho: a honestidade na escrita deve prevalecer. É essa a sua grande arte poética construída ao longo de sua obra. No mesmo golpe em que noticia sua arte poética, desloca-a de um substantivo, propriamente dito. Não se trata, aqui, de discursar sobre uma substância, que pudesse atravessar e permanecer sendo essencialmente a mesma em todas as 
produções de um período, ou de uma nação, ou de um modo de um trabalho, como o é aquele com as palavras. Uma substância, claro está, que poderia ser colorida por adjetivos, tais como: engajada, política, social. Antes, a arte torna-se advérbio, qualificando, aqui, os verbos, ações. As artes poéticas de Knopfli são modos de se apropriar de um gesto. As suas tentativas de escrever uma "arte poética" esbarram sempre neste aspecto, a despeito de outras variantes: a honestidade em escrever somente o que tenha pra si alguma experiência e vivência.

Que o ser-lhes fiel, me não desobrigue

da fidelidade à fidelidade, ao sangue e à voz.

Que, anacrónico, discursivo, explícito, negado, escarnecido e reduzido ao limbo, um homem de gravata e fato escuro, contrariando

o sentido único do tráfego, a horda irreprimível da excepção endémica desdobrada, por contágio, em excepção generalizada, eu venha, ad absurdum, a constituir a excepção da excepção. Que as palavras sejam, pois, não uma exclusiva volição

de ser ou de significar; se conduzam, porém, de tal forma que, em significando, sejam e, sendo, signifiquem; e uma e outra coisa se interpenetrem e interliguem, tão aturada e porfiadamente, que obstruam e interditem todo e qualquer escrutínio

unilateral, sendo, como tornadas são, objetivo outro e não a soma das parcelas integrantes.

E que a predominância de um dos termos arraste consigo a perda irremediável da totalidade acabada e unívoca. E que, por fim, tendo

de incorrer em qualquer dos nomeados riscos ou danos, incurso seja menos por ser do que pelo obstinado zelo de significar. Nenhum inferno é maior que o da voz traída e nenhum bem vale o da sua integridade.

A fidelidade está acima de tudo, e é justamente por ela que o poeta marca a sua diferença. É por causa dela que o poeta contraria o "sentido único do tráfego", e torna-se uma exceção num mundo de exceções, uma referência aos outros poetas que, tendo, em seus poemas, apelo ideológico muito forte, ansiavam o poder de comunicar, de significar. 
Aqui, tudo a que o sujeito anseia é manter-se íntegro. E, ainda, que seus versos não possam ser julgados senão pelo que são, ou seja, que não haja, neles, o desejo de comunicar, de significar, mas que faça mais (ou menos): que fidelize. Havendo, neles, qualquer termo predominando, ele estará comprometido, tendo em vista que funciona como um organismo, ou, ao menos, assim o sujeito almeja.

Não bastassem essas indicações que o poeta nos dá, o título extremamente explícito demonstra o desejo de delimitar a leitura de seus versos, ou, talvez, somando título e texto, seja um alerta ao leitor. Um aviso para que não busque ali um referente que não seja a própria poesia. Não um jogo de palavras vazio, como dissemos anteriormente, mas uma coisa outra que só pode ser em sua totalidade, só pode existir na união entre existência e significado. Algo que supera o próprio sujeito por trás dos versos, que o ultrapassa.

Sobre isso, Noa (1997) escreve:

[...] a poesia de Rui Knopfli preocupa-se não só em dizer o mundo interior e exterior, como também em representar a própria escrita que se autolegitima, que se autorregula e mesmo se autoprescreve. [...]

Portanto, no dizer-se, na busca incessante de sua essência e origem, a palavra poética, auto-exploratória, torna-se protagonista do poema $[. .$.

(p. 121-122)

A seção "Pórtico" abre o segundo livro de Knopfli, Reino Submarino, de 1962; bastante significativo já pelo título. "Pórtico" significa, segundo o dicionário Aulete:

1. Portal ornamentado, luxuoso, na entrada de um edifício, palácio etc.; portada; portal.

2. Espaço coberto cuja abóboda é sustentada por colunas e que serve de entrada ou vestíbulo.

3. A via de acesso a algo que é considerado difícil ou grandioso.

Abre-se seu livro com um portal, por ali se adentra o livro, mas é também por ali que se adentra a poesia de Knopfli. A exemplo da seção que lhe sucede, "Pórtico" é formada por três poemas: "Chave", "Aprendiz na oficina da poesia" e "Ofício novo". 0 primeiro deles, "Chave", cujo título autoexplicativo complementa o da seção, abriria o portal, assumindo a perspectiva "submarina" do livro. Fala do que está submerso e que 
raramente vem à superfície. Mas esse processo de emersão não acontece sem sofrimento, sem trabalho.

\section{CHAVE}

Murmúrio longínquo, ininteligível

voz remota,

som indistintamente audível.

Voz que pára

e cala aflita

e se suspende

e como que medita.

Chama abissal, voz imersa

nos imensos silêncios subaquáticos.

Palavras paradas,

gritos afogados

em pulmões repletos de água.

Palavras que lutam

instáveis, monocórdicas,

ou insonoras

e que opressas

e submersas

anseiam a calma das superfícies.

Voz que teme

e se insinua.

Que se arrasta

humilde e estrema

no escuro lodo das profundezas.

Palavras imperfeitas

que se esgueiram

e sobem à tona

e penetram doloridas

nos espaços oxigenados.

Nesse poema, podemos presenciar o processo de ascensão das palavras à superfície. As palavras se confundem com as vozes que vêm de algum lugar longe e que, a princípio, não se entende, mas se escuta, quase como um chamado. As imagens vão, cada vez mais, sufocando, afogando as palavras e as vozes. Essa experiência é regada por um sofrimento - não é simples levar às palavras à superfície. A imagem de um pulmão já 
repleto de água também nos traz a ideia de que algo, além de oprimir as palavras, oprime também aquele que as quer dizer. Algo os afoga, os silencia. Mas há uma ânsia pela superfície, há a necessidade de dizê-las, acima de qualquer coisa é necessário desafogar essas palavras, dar-lhes respiro, bem como ao pulmão de quem as pronuncia. A poesia, então, seria necessidade vital. As palavras são humildes, se arrastam nas profundezas, e também são imperfeitas, mas precisam ascender e, num processo dolorido, elas "penetram os espaços oxigenados". O verbo "penetrar" também é prenhe: parece que há, ali, uma falha, um espaço que ninguém percebe, por onde as palavras se "esgueiram" e adentram. Essas palavras não estão nas profundezas por vontade própria, mas foram a isso obrigadas, foram "afogadas", a voz foi silenciada e sonha em conquistar seu espaço.

Cabe destacar, aqui, o papel crucial que as palavras assumem. Elas são protagonistas dessa poesia. Subjaz sempre um sujeito que as organiza, mas esse sujeito também só pode fazer isso e o resultado supera palavras e sujeito, tornando-se outra coisa, ganhando autonomia.

Levando em consideração o contexto de Knopfli, a sua poesia estava sem lugar, submersa, mas, mesmo assim, encontrava um modo de vir à tona. Desse modo, as palavras abrem seu próprio espaço, aí está a "chave" da poesia de Knopfli. As palavras, mesmo que imperfeitas e humildes, diante da opressão, encontram doloridamente um espaço para "respirar". Carreiro (1998, p. 68) diz-nos:

Amante das palavras, o poeta, aturada e pacientemente, espera que germinem em si para artisticamente colhê-las e colocá-las na matriz. Desta emergência dificultosa da palavra procede a consciência crítica de que a superfície calma do poema é inscrita sobre tons aflitivos e silêncios subaquáticos.

A esse poema, sucede-se "Aprendiz na oficina da poesia", que, por sua vez, quase repete o poema "Chave", mas em outras imagens. Agora, ao invés da imagem subaquática, é a imagem da maturação de frutos que substitui o lugar do fazer poético.

\section{APRENDIZ NA OFICINA DA POESIA}

Não rimes.

Ou rima, se quiseres, mas não violentes

a palavra.

Não busques ansioso, 
qual amante inexperiente,

a palavra.

Espera antes

a sua vinda.

Música e rima

são acessórios dispensáveis:

0 poema é outra coisa.

Deixa, pois

que as palavras acordem

na matriz

e caiam maduras.

Áridas ou frias,

secas e imperturbáveis,

orvalhadas, humildes,

estropiadas até,

que sejam precisas,

prenhes de significado.

Espera as palavras.

Elas viajam misteriosas, desconhecidas ainda, elas germinam em ti.

Caem. Juntam-se.

Doloridas, feias

sob o visco placentário, deselegantes por vezes,

elas procuram-se

e organizam-se.

Juntas transcendem-se,

há algo de íntimo,

coeso e secreto

nelas.

O poema está aí.

Podemos ver claramente que as palavras germinam e caem, não são colhidas. $\mathrm{Ou}$ seja, o poeta não escolhe quando acontece, apenas espera que elas estejam prontas a "emergir" ("Deixa, pois/ que as palavras acordem/ na matriz/ e caiam maduras./ [...] desconhecidas ainda,/ elas germinam/ em ti."). A imagem do amante inexperiente revela a íntima ligação do sujeito com a poesia e também alguma maturidade, tendo em vista que ele já não seria um amante inexperiente. 
As palavras são imperfeitas, humildes, estropiadas, deselegantes, mas são também prenhes de significado e transcendem-se, ou seja, mais uma vez, de forma dolorida, o poema desabrocha, mas abre as portas para algo maior e para a diversidade da leitura, como temos ressaltado. 0 poema carrega consigo uma áurea didática, como se o aprendiz dessa oficina estivesse diante de seu professor. 0 sujeito está ensinando a fazer um poema, descortinando todo um respeito às palavras, que mais uma vez protagonizam o poema, sendo elas a grande razão de ser do poema e subjazendo um sujeito quase invisível, que quase se retira em favor das palavras, mas que projeta, traça, organiza as palavras em algo que é, ao final, o poema.

\subsection{Por trás da palavra}

Em "Poesia ilustrada ou divertimento para duas flores e um poeta", Knopfli evoca, mais uma vez, a imagem da rosa. No entanto, dessa vez, ele parece tentar desenhá-la, e a vai descrevendo, tentando apreendê-la em palavras, enquanto nos vai dizendo que a está desenhando. 0 sujeito desiste da rosa, e aplica a mesma técnica ao malmequer, porém, mais uma vez, sem sucesso. Ao final:

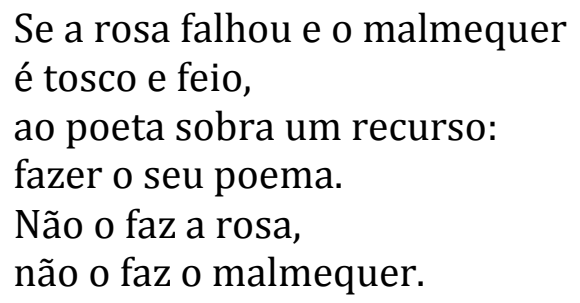

O sujeito assume, portanto, um papel ativo na produção do poema. Ele não pode apreender essas flores de outro modo que não em poema, ele não pode desenhá-las, mas pode descrevê-las e, ao fazê-lo, faz também o poema. Sob o título longo, o sujeito já se enuncia e também demonstra que se entretém ao fazer o poema, mais que isso, ao fazer um poema sobre o poema, sobre fazer o poema. Também antecipa muito do que está por vir no poema.

Sobre isso, Francisco Noa (1997) diz: 
[...] estes título não só estabelecem uma "ligação catafórica" (GUIMARÃES, 1990, p. 52) com aquilo que se segue, induzindo a uma dada leitura do texto, como também, e por isso, assumem uma "função cognitiva" e uma "função articuladora" no processo de organização e no da desconstrução do texto. (p. 121)

Ou seja, mais uma vez, Knopfli intervém, portanto, na leitura de seus poemas. E, ao anunciar a presença de um sujeito captador e organizador dos versos, Knopfli representa a própria escrita, regulando o próprio discurso e também dando a ele a validade necessária.

Esse sujeito organizador e construtor do poema insinua-se outras vezes como captador dessas palavras. Por exemplo, em $O$ escriba acocorado, no poema "XV. Posposição", lê-se:

\section{[...]Curvo-me sobre esta}

morosa, pertinaz escrita. Ausculto a ténue

respiração da noite e da quietude. Sob o débil

crepitar do metal percorrendo o papel soa

perturbada a harmonia distante do universo.

Aqui, podemos ver que o poeta é um instrumento da escrita, mas, novamente, não uma figura passiva. É um trabalho que exige dedicação, mas suas palavras, ou, antes, as palavras que ele escuta, que persegue, revelam algo que excede ao poeta e também às próprias palavras. Novamente citando Noa:

Reflectir na literatura através da própria literatura constitui, no fundo, uma busca da plenitude da linguagem, na exploração ilimitada das suas capacidades plásticas, expressivas e significantes. (NOA; 1997, p. 123)

Dessa forma, Knopfli não se ausenta de sua poesia, mantendo-se fiel ao seu discurso de que é preciso ter "tripas", ele mesmo se insere em seus poemas, caracterizando a validade de seus versos por ninguém menos do que ele próprio. Assim, prescinde de uma crítica que o faça. Essa talvez seja a maior função de sua escrita autorreguladora.

Em “O poeta é um fingidor", essas duas dimensões parecem se alinhar, se amalgamar de um modo bastante intenso. Vejamos: 


\author{
Entreteço palavras \\ na malha áspera destes versos \\ e a tessitura triste que faço \\ mais esmorece no azul baço \\ do papel. Entristeço então \\ a alma numa renda miúda \\ e apertada de ponto incerto \\ e complicado. Estabeleço assim \\ dois mundos convergentes: \\ A textura entristecida dos versos \\ e a tristeza entretecida da alma. \\ E logo esqueço onde tudo isto \\ teve começo: \\ Se de entristecer palavras, \\ se de entretecer sentimentos, \\ se de constranger a alma, \\ se de contristar palavras: \\ se me contristei constrangendo, \\ se me constrangi contristando.
}

Sei que me contristo entretecendo e me entreteço de tristeza.

Percebe-se, aqui, a junção entre ser e escrever. As palavras têm a sua autonomia sempre vigiada por uma entidade organizadora, Essa entidade, em algum momento, se perde, já não se sabe mais se é quem organiza as palavras ou se é por elas organizada. Mas é justamente ela quem estabelece a junção dessas duas instâncias ("Estabeleço assim/ dois mundos convergentes"). Ser e escrever passam a se confundir. A autonomia da palavra não é perseguida, a entidade organizadora não desaparece, mas fazem parte de uma mesma trama, numa rede em que versos e poeta se confundem no ato de ser. Ambos trazem, como elemento unificador, a tristeza, o sofrimento, e o jogo com as palavras "constranger", "contristar", "entretecer" e "entristecer", sonora e semanticamente próximas, aproxima ainda mais a subjetividade dessa entidade e o que ela produz. Assim, forma-se um emaranhado de palavras para tramar e entretecer a rede sobre a qual se deita a sua obra.

A fusão dos mundos se dá justamente pela experiência do sujeito misturada à experiência dos versos, ambos tristes, constrangidos, de tal maneira que ambos partilham um modo de ser, uma características intrínseca que os une. Assim, Knopfli traz à sua poesia o mesmo que vimos em suas entrevistas, ou seja, as "tripas", a 
experiência, a visceralidade, mantendo-se fiel aos seus pronunciamentos sobre a obra e sobre o ato de escrever. Há, portanto, uma simbiose entre palavras e subjetividade, numa relação de benefício mútuo, que dá origem a um terceiro organismo, isto é, não é sujeito, não é mais palavras, é poema.

Knopfli assume, portanto, um processo de criação multifacetado do sujeito que por vezes se que apresenta como senhor das palavras ("ao poeta sobra um recurso:/ fazer o seu poema./ Não o faz a rosa./ Não o faz o malmequer."), e, em outros momentos, está apenas a serviço delas, como um instrumento de sua vontade, uma antena que as capta ("Curvo-me sobre esta/ morosa, pertinaz escrita. Ausculto a ténue/ respiração da noite e da quietude. Sob o débil/ crepitar do metal percorrendo o papel soa/ perturbada a harmonia distante do universo."). Este modo de criação não é linear. Em sua obra, predominam os poemas cujo sujeito organizador está sempre presente, organizando as palavras de acordo com a sua subjetividade, de acordo com a sua experiência, e onde as palavras têm sua autonomia sempre relativizada em função dessa experiência, constituindo não só a experiência do sujeito com relação ao mundo externo e interno, mas também uma poesia da própria poesia. Esse movimento em direção à própria poesia, ou seja, de poetizar a criação poética parece manifestar a busca por uma essência da poesia. Uma busca que levaria o sujeito a entender o que sente ao criar e o que cria com os sentimentos. Une, portanto, duas vertentes essencialistas: aquela em que o sujeito se enuncia como possuidor da palavra e a outra, em que as palavras fazem o sujeito desaparecer, assumindo assim uma posição diferente dessas duas, longe de estar a meio caminho de qualquer delas. Assim, Knopfli alimenta o seu desejo de que "as palavras sejam, pois, não uma exclusiva volição/ de ser ou de significar; se conduzem, porém,/ de tal forma que, em significando, sejam, e sendo,/ signifiquem”.

O poema, portanto, dentro da obra de Knopfli, é uma criatura do poeta, mas que também o cria, e invariavelmente supera, na perspectiva knopfliana, palavra e sujeito. Outro exemplo para vislumbrarmos essa amálgama, podemos encontrar no seguinte poema:

\section{IDEIA DO POEMA}

Fluída, indecisa, volátil, inconcreta, a ideia não se submete facilmente ao cerco insidioso 
da palavra.

\author{
Elusiva \\ e ambígua a cada \\ instância se lhe furta, \\ presa de um discreto pudor. \\ A palavra é, porém, \\ audaciosa, pertinaz, envolvente. \\ Persegue-a e espreita-a, \\ faz-lhe longas esperas \\ e sai-lhe ao caminho \\ a horas inesperadas, em lugares \\ incertos. \\ Cativa-a \\ e perturba-a lentamente \\ subverte-lhe a vontade, \\ exalta-lhe os sentidos \\ e, amorosamente, \\ nela penetra, desfigurando-a. \\ Da ideia já nada, \\ ou quase, sobra. \\ Senão o poema.
}

Se, no poema anterior, a presença do "eu" era quem estabelecia a convergência de dois mundos, aqui, cabe às palavras cercar a ideia, cortejá-la, transformá-la em algo diferente do que era a princípio. Desta vez, terceiro organismo formado na junção simbiótica entre palavra e ideia, em que a "ideia" representa a subjetividade, é enunciado explicitamente no último verso. É fruto de uma junção amorosa, neste poema, diferentemente do anterior, em que a ligação entre elas se dava pela tristeza. Há uma espécie de cortejo por parte da palavra. A "ideia" age como uma figura feminina, que se insinua à palavra, que a provoca, ambiguamente. Mas é, aos poucos, cativada, ao "subverter-lhe a vontade", a palavra assume o controle da situação e quando "exalta-lhe o sentido", já anuncia a fusão que vem na estrofe seguinte. Afinal, o que é plurissignficativo, a ideia ou a palavra? E, ainda, quando "amorosamente" a palavra penetra a ideia, temos justamente a ligação simbiótica que destacamos anteriormente, formando, explicitamente, o poema ("da ideia já nada,/ ou quase, sobra./ Senão o poema."). 


\section{CONCLUSÃO}

Na última parte deste trabalho, buscamos realizar uma análise da poesia sobre a poesia, ou seja, a perspectiva metapoética na obra de Rui Knopfli. Mostramos, portanto que, se retomarmos todas essas características de sua obra, veremos que ele não rompe com aquela fidelidade aos seus versos, à sua experiência, ao seu não alinhamento. Mantendo-se presente em seus versos e deixando as palavras atuarem nas ideias, Knopfli produz uma poesia sem precisar recorrer aos critérios ideológicos de seus contemporâneos. Recurso que ele próprio nega por não ter a vontade de fazê-lo, não ter nada significativo pra si que o faça adotar essa temática. Nega também o alinhamento ideológico ao inimigo de seus contemporâneos, os portugueses. Também não pode assumir essa bandeira por ter naquele território as suas experiências mais significativas. Apenas a si próprio ele pode, portanto, ser fiel. Essa fidelidade lhe custou certo exílio a que o poeta se impôs ao acreditar não ser mais bem-vindo em território moçambicano após a independência pela leitura equivocada de sua obra em oposição à daqueles que lutaram por um projeto de nação e de identidade nacional.

Knopfli usa e abusa da intertextualidade e da metapoética, para autolegitimar a sua produção e, portanto, prescindir de uma crítica que o faça, tendo em vista que o ataque mais intenso à sua obra foi o de cunho ideológico, que criticava o seu não alinhamento político diante da conjuntura de Moçambique e, baseado nisso, julgava a validade dos versos de Knopfli. Uma poesia filiada à tradição ocidental, mas não mera continuadora desta, tendo em vista a proximação que promove com os espaços africanos, não apenas físicos, mas cotidianos, ainda que impere a presença citadina, a 
diluição metropolitana. E a cidade, operando como um espaço centralizador de muitas identidades acaba por tê-las todas enfraquecidas.

Talvez ainda mais drástico que isso, o poeta propõe um jogo limítrofe com o leitor-consumidor de seu tempo. Bem sabemos, os objetos de consumo são produzidos, cada vez mais, ao gosto da clientela, para que ela própria não mude. Ou mude, mas mude de produto, e prossiga consumindo. De modo que, antes de tudo, o que deve mudar é o objeto de consumo, em nosso caso, o livro de poemas moçambicano.

Esse jogo comercial e contemporâneo de consumo supõe que o consumidor já esteja consumado: de gostos mais ou menos previsíveis, ávido por livros de um tal ou qual gênero, dispondo de algum dinheiro, é livre para, diante de uma prateleira, escolher o livro que mais lhe apeteça.

A liberdade, nesse sentido, não é mero detalhe desse jogo: ela é a regra primeira do jogo; sem ela, não há consumo; há planos quinquenais, há racionamento, há ditadura, não consumo. A liberdade, no caso dos livros, supõe também que o leitor se sinta livre para se apropriar do modo que melhor lhe aprouver dos conteúdos dos livros.

Essa liberdade, Knopfli não concede a seu leitor. A cada instante, admoesta-o: não me leia com esses óculos, troque sua lente, corrija sua miopia. Quando constrange dessa forma seu consumidor, quando inventa seu leitor - aquele que já não pode ser o mesmo que leu Craveirinha semana passada, nem o que leu Shakespeare ontem, nem o que leu o jornal hoje pela manhã - quando, enfim, cria não só sua própria poesia, não só seu modo de confeccioná-la, não só sua crítica, mas também seu leitor, agora não tão livre quanto se sentia debitando em sua conta bancária mais uma obra poética nos balcões da livraria, Knopfli cria também, além dos demais, problemas para a escrita, a publicação e a circulação de livros em seu tempo.

Assim, fecharam-se, por muito tempo, os olhos para as qualidades de sua obra, qualidades que tentamos aqui salientar, sem esconder também as contradições entre discurso e obra, dentro do próprio discurso e dentro da própria obra. Qualidades que assumidamente não se alinhavam ao discurso vigente e que foram sustentadas até a morte de Knopfli nos brios daquela honestidade que tanto citamos, honestidade que talvez seja, ao fim e ao cabo, a verdadeira obra poética de Knopfli. 


\section{BIBLIOGRAFIA}

1. ALBUQUERQUE, Orlando de \& MOTTA, José Ferraz. História da literatura em Moçambique. Braga: Edições APPACDM Distrital de Braga, 1998.

2. ANDERSON, Benedict. Nação e consciência nacional. São Paulo: Ática, 1989.

3. APPIAH, Kwame Anthony. Na casa de meu pai: a África na filosofia da cultura. Rio de Janeiro: Contraponto, 1997.

4. ASHCROFT, Bill, GRIFFITHS, Gareth \& TIFFIN, Helen. The empire writes back: Theory and practice in post-colonial literatures. New York, Routledge, 1989.

5. BHABHA, Homi K. O local da cultura. Belo Horizonte: UFMG, 2001.

6. BLOOM, Harold. A angústia da influência: uma teoria da poesia. $2^{a}$ ed. Rio de Janeiro: Imago Ed., 2002.

7. CABAÇO, José Luis de Oliveira. Moçambique: identidades, colonialismo e libertação. Tese de Doutorado. Universidade de São Paulo, 2007.

8. CARREIRO, José Maria Aguiar. Memória Consentida. In: Informar - Revista de Acção Educativa no 26, Armando Dutra (dir.), Ponta Delgada, edição do Centro de Apoio Tecnológico à Educação, Maio/ Agosto de 1998, pp. 63-68.

9. $\quad$ CHABAL, Patrick. Vozes moçambicanas. Lisboa: Vega, 1994.

10. DÁSKALOS, Maria Alexandre, APA, Livia \& BARBEITOS, Arlindo. Poesia africana de língua portuguesa (antologia). Rio de Janeiro; Lacerda Editores, 2003.

11. Chaves, R. Angola e Moçambique: experiência colonial e territórios literários. São Paulo: Ateliê Editorial, 2005.

12. CHAVES, R. José Craveirinha, da Mafalala, de Moçambique, do Mundo. Revista Via Atlântica. USP-DLCV, n. 3, 1999. pp. 140-168.

13. CRAVEIRINHA, José. Cela 1. Lisboa: Edições 70, 1980.

14. CRAVEIRINHA, José. Karingana ua karingana. Lourenço Marques: Académica Lda, 1974.

15. CRAVEIRINHA, José. Xigubo. 2 ed. Lisboa/Maputo: Edições 70 / Instituto Nacional do Livro e do Disco, 1980.

16. EAGLETON, Terry. A ideia de cultura. São Paulo: Editora Unesp, 2011.

17. EAGLETON, Terry, JAMESON, Fredric \& SAID, Edward W. Nationalism, colonialism and literature. Minneapolis: University of Minnesota Press, 1997. 106

18. ELIOT, Thomas Stearns. Tradição e Talento Individual. In: Ensaios. Trad. e int. Ivan Junqueira. São Paulo: Art Editora, 1989. p. 37-48.

19. FERREIRA, Manuel. Literaturas africanas de expressão portuguesa. São Paulo: Ed. 
Ática, 1987.

20. FERREIRA, Manuel. No reino de Caliban III - Moçambique: antologia da poesia africana de expressão portuguesa. Lisboa: Plátano Editora, 1984.

21. HALL, Stuart. $A$ identidade cultural na pós-modernidade. $6^{\mathbf{a}}$ ed. Rio de Janeiro: DP\&A, 2001.

22. HALL, Stuart. Da diáspora: Identidades e mediações culturais. Liv Sovik (org). Belo Horizonte: Editora UFMG; Brasília: Representação da UNESCO no Brasil, 2003.

23. Dicionário Caldas Aulete. Disponível em: http://aulete.uol.com.br. Acessado em 21 de outubro de 2011.

24. HUTCHEON, Linda. Poética do pós-modernismo: história, teoria, ficção. Rio de Janeiro; Imago, 1991.

25. JORGE, Sílvio Renato. "José Craveirinha e a busca da palavra moçambicana". In: CAMPOS, Maria do Carmo Sepúlveda e SALGADO, Maria Teresa. África \& Brasil: Letras em laços. Rio: Atlântica, 2000. pp.197-208.

26. Knopfli, Rui. O denominador comum. Revista Colóquio/Letras. no.110/111, Julho 1989, p. 99-107.

27. KNOPFLI, Rui. Obra poética. [Escritores dos países de língua portuguesa, no 31] Lisboa: INCM, 2003.

28. Knopfli, Rui. A ilha de próspero. Lourenço Marques: Minerva Central, 1972.

29. LABAN, Michel. Moçambique: encontro com escritores. Porto: Fundação Engenheiro António de Almeida, 1998. v.2.

30. LARANJEIRA, Pires. Literaturas africanas de expressão portuguesa. Lisboa: Universidade Aberta, 1995.

31. LEITE, Ana Mafalda. A fraternidade das palavras. Via Atlântica, n. 5, 2002. p. 2029.

32. LEITE, Ana Mafalda. Literaturas africanas e formulações pós-coloniais. Maputo: Universidade Eduardo Mondlane, 2003.

33. LISBOA, Eugénio. Poesia de Moçambique-1. Lourenço Marques: Minerva Central, s/d.

34. LORENZ, Günter. Diálogo com Guimarães Rosa. In: ROSA, João Guimarães. Ficção completa em dois volumes, volume I. Rio de Janeiro: Nova Aguilar, 2009, pp. 6263)

35. LUGARINHO, Mário. Dizer "eu” em África - poesia e subjetividade. Scripta, Belo Horizonte, v. 7, n. 13, p. 314-319, 2003.

36. MARGARIDO, Alfredo. Estudos sobre literaturas das nações africanas de língua portuguesa. Lisboa: A Regra do Jogo, 1980.

37. MATUSSE, Gilberto. A construção da imagem de moçambicanidade em José Craveirinha, Mia Coutro e Ungulani Ba Ka Khosa. Maputo: Livraria universitária, 1997.

38. MELONI, O. H. Cosmopolitas da mesma aldeia: dois pilares da poesia moçambicana Disponível em: <http://www.ufjf.br/darandina/files/2010/01/Otavio-HenriqueMeloni.pdf>

39. MENDONÇA, Fátima. O conceito de nação em José Craveirinha, Rui Knopfli e Sérgio Vieira. Via atlântica, São Paulo, n. 5, pp. 55-57.

40. MONTEIRO, Fátima. O País dos outros: a poesia de Rui Knopfli. Portugal: Imprensa Nacional Casa da Moeda, 2003.

41. MOURALIS, Bernard. As contraliteraturas. Coimbra: Almedina, 1982.

42. NOA, Francisco. A escrita infinita. Maputo: Universidade Eduardo Mondlane, 
1998.

43. NOA, Francisco. Império, mito e miopia: Moçambique como invenção literária. Lisboa: Editorial Caminho, 2002.

44. NOA, Francisco. Literatura moçambicana: memória e conflito. Maputo: Universidade Eduardo Mondlane, 1997.

45. PAZ, Octavio. $O$ arco e a lira. $2^{\text {a }}$ ed. Rio de Janeiro: Nova Fronteira, 1982.

46. PAZ, Octavio. Os filhos do barro. 2 ${ }^{\mathrm{a}}$ ed. Rio de Janeiro: Nova Fronteira, 1982.

47. PEREIRA, José Carlos Seabra, «Flores, árvores e frutos na poesia de Rui Knopfli: uma faceta da expressão da identidade individual no contraponto de Heimat e de desenraizamento» in Les Littératures Africaines de Langue Portugaise, Paris, F.C. Gulbenkian, 1985, pp. 397-406.

48. REVISTA LER no 34 (Primavera 96). Lisboa: Círculo de Leitores, 1996.

49. SAID, Edward W. Cultura e imperialismo. São Paulo: Companhia das Letras, 1995.

50. SAID, Edward W. Orientalismo. São Paulo: Companhia das Letras, 2001.

51. SANTIAGO, Silviano. Uma literatura nos trópicos: ensaios sobre dependência cultural. $2^{\mathrm{a}}$ ed. Rio de Janeiro: Rocco, 2000.

52. SANTILLI, Maria Aparecida. Estórias africanas: história e antologia. São Paulo: Ed. Ática, 1985.

53. SAÚTE, Nélson \& SOPA, António. A Ilha de Moçambique pela voz dos poetas. Lisboa: Edições 70, 1992.

54. SECCO, Carmen Lucia Tindó Ribeiro (org.). Antologia do mar na poesia africana de língua portuguesa do século XX, volume III: Moçambique, São Tomé e Príncipe e Guiné-Bissau. Rio de Janeiro: UFRJ, Coordenação dos cursos de pós-graduação em Letras Vernáculas e Setor de Literaturas Africanas de Língua Portuguesa, 1999.

55. SERRA, Carlos. Identidade, moçambicanidade, moçambicanização. Maputo: Universidade Eduardo Mondlane, 1998.

56. SHAKESPEARE, William. The Tempest. Essex: Longman, 1985

57. THOMAZ, O. R. Relações raciais em Moçambique: histórias sobre autóctones e forasteiros. In: PEIXOTO, F. A.; Pontes, H.; SCHWARCZ, L. M. (orgs). Antropologias, histórias, experiências. Belo Horizonte: Editora UFMG, 2004.

58. VOLPE, Miriam L. Geografias de Exílio. Juiz de Fora: Editora UFJF, 2005. 